Portland State University

PDXScholar

\title{
Assessment of Needs of Adolescent Mothers in Washington County
}

\author{
John L. Arnold \\ Portland State University \\ Jean C. Austin \\ Portland State University \\ Gary L. Brink \\ Portland State University \\ Jane Hall \\ Portland State University \\ Patricia C. Hanson \\ Portland State University
}

See next page for additional authors

Follow this and additional works at: https://pdxscholar.library.pdx.edu/open_access_etds

Part of the Family, Life Course, and Society Commons, and the Social Work Commons Let us know how access to this document benefits you.

\section{Recommended Citation}

Arnold, John L.; Austin, Jean C.; Brink, Gary L.; Hall, Jane; Hanson, Patricia C.; Ivey, Valerie A.; Moran, April A.; Pank, John P.; Skolnick, Mark J.; Tarr, James A.; and Vaughn, Roberta B., "Assessment of Needs of Adolescent Mothers in Washington County" (1981). Dissertations and Theses. Paper 3447.

https://doi.org/10.15760/etd.5331

This Thesis is brought to you for free and open access. It has been accepted for inclusion in Dissertations and Theses by an authorized administrator of PDXScholar. Please contact us if we can make this document more accessible: pdxscholar@pdx.edu. 


\section{Author}

John L. Arnold, Jean C. Austin, Gary L. Brink, Jane Hall, Patricia C. Hanson, Valerie A. Ivey, April A. Moran, John P. Pank, Mark J. Skolnick, James A. Tarr, and Roberta B. Vaughn 


\title{
ASSESSMENT OF NEEDS OF ADOLESCENT MOTHERS
}

IN WASHINGTON COUNTY

\author{
by \\ JOHN L. ARNOLD \\ JEAN C. AUSTIN \\ GARY L. BRINK \\ JANE HALL \\ PATRICIA C. HANSON \\ VALERIE A. IVEY \\ APRIL A. MORAN \\ JOHN P. PANK \\ MARK J. SKOLNICK \\ JAMES A. TARR \\ ROBERTA B. VAUGHN
}

A practicum submitted in partial fulfillment of the requirements for the degree of

MASTERS IN SOCIAL WORK

Portland State University

April, 1981 
Approved:

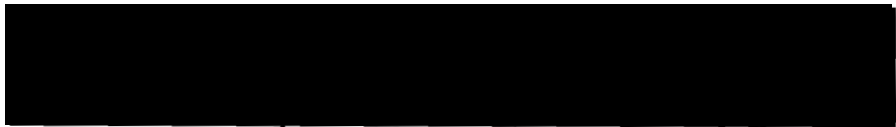

Nancy M. Koroloff, Assistant Praíssor 


\section{ACKNOWLEDGEMENTS}

We extend special acknowledgement to the Washington County Task Force on Adolescent Pregnancy for their contribution to this study. In addition, thanks are due to the participating service providers and adolescent mothers.

Credit is also extended to Nancy Koroloff, our instructor and technical consultant. Without her assistance and support this project could never have been fulfilled.

Additional support and assistance were provided by Iinda Dreyer of the Research Institute. 
TABLE OF CONTENTS

PAGE

ACKNOWLEDGEMENTS . . . . . . . . . . . . . . . . . . . . iii

LIST OF TABLES . . . . . . . . . . . . . . . . . . . . . . vi

LIST OF FIGURES . . . . . . . . . . . . . . . . . . . . vii

CHAPTER

I SUMMARY AND RECOMMENDATIONS. . . . . . . . . . . . . 1

II DEMOGRAPHIC DESCRIPTION OF WASHINGTON COUNTY . . . . . . 12

Introduction ............... 12

Highlighted Findings .............. 12

Methodology ................ . 14

Limitations . . . . . . . . . . . . . 14

Overview of Washington County .......... 15

Socio-economic Indicators ........... 18

Health and Vital Statistics . . . . . . . . 21

III CHARACTERISTICS OF THE SERVICE PROVIDERS . . . . . . . 26

Introduction............... 26

Methodology .................. . 26

Characteristics of Service Providers Interviewed . . 28

Description of Clients Served ......... 30

Services Available to Adolescent Mothers....... 31 
Interagency Linkages .. . . . . . . . 37

Agency Philosophy, Future Plans, and Funding . . . 38 IV DESCRIPTION OF THE TARGET POPULATION . . . . . . . . . 43

Introduction ................. 43

Description of Questionnaire... . . . . . . 43

Limitations . . . . . . . . . . . . 44

Health Care ............... 50

Education ................... 54

Services Received .............. 57

FOOTNOTES . . . . . . . . . . . . . . . . . . . 63

APPENDIX A . . . . . . . . . . . . . . . . . . 65

Annotated Bibliography ............ 65

APPENDIX B . . . . . . . . . . . . . . . . . . . 71

Additional Tables $(A-I)$. . . . . . . . . 71

Table J: Agencies Included in Survey . . . . . 75

Map of Washington County Service Providers . . . . 76

APPENDIX C . . . . . . . . . . . . . . . . . . 77

O.R.S. 343.077 ................. 77

APPENDIX D . . . . . . . . . . . . . . . . 78

Cover Letter: Service Providers' Questionnaire . . . 78

Service Providers' Questionnaire . . . . . . . . 79

Cover Letter: Young Mothers' Needs Assessment . . . 86

Young Mothers' Needs Assessment .. . . . . . 87 


\section{LIST OF TABLES}

I Number of Service Providers, by Area . . . . . . . . . 29

II Referral Sources . . . . . . . . . . . . . . . 31

II Services Available . . . . . . . . . . . . . 32

IV Services Used Most Often by Adolescent Mothers . . . . . 33

$\mathrm{V}$ Age of Respondents ................. 46

VI City of Residence . . . . . . . . . . . . . . 47

VII Respondents' Living Arrangements . . . . . . . . . . 47

VIII Source of Financial Support . . . . . . . . . . . 48

IX Income Status of Respondents . . . . . . . . . . . . 49

X Age, Marital Status and Income Levels . . . . . . . 50

XI Respondents Currently Pregnant ............... 51

XII Respondents Who Planned Pregnancy . . . . . . . . . . 51

XIII Respondents Previously Pregnant . . . . . . . . . 52

XIV Prenatal Care Received . . . . . . . . . . . 53

XV Source of Prenatal Care . . . . . . . . . . . 53

XVI Schools Attended Before Pregnancy . . . . . . . . . . 55

XVII Schools Attended After Pregnancy . . . . . . . . . . 55

XVIII Reasons for Not Continuing Education . . . . . . . . . 56

XIX Education Aspects . . . . . . . . . . . . . 57

XX Services Wanted During and After Pregnancy . . . . . . . 58

XXI Services Received During and After Pregnancy . . . . . . . 59 
XXII Service Sources . . . . . . . . . . . . . 60

XXIII Information Sources ................ 61

A. Live Births . . . . . . . . . . . . . 71

B. Teenage Births (Under 15 Years of Age) . . . . . . 71

C. Teenage Births (15 - 19 Years of Age). . . . . 72

D. Abortions (total) ............. 72

E. Abortions (Under 15 Years of Age) . . . . . . . . 72

F. Abortions (15 - 19 Years of Age) . . . . . . . 73

G. Immature Births (2500 Grams or Less) . . . . . . 73

H. Unwed Births (Under 15 Years of Age) . . . . . . 73

I. Unwed Births (15 - 19) Years of Age) . . . . . . . 74

J. Agencies Included in Survey . . . . . . . . . 75 


\section{LIST OF FIGURES}

FIGURE

PAGE

1. Washington County Population, 1975-1980 . . . . . . . . 17

2. Live Births in Washington County .............. 22

3. Unwed Births to Adolescents ( 19 Years of Age and Under) in Washington County . . . . . . . . . . . . 23

4. Abortions in Washington County . . . . . . . . . . . 24

5. Sources of Agency Funding . . . . . . . . . . . . 39

6. Allocation of Agency Funds for Services to Adolescent

Mothers . . . . . . . . . . . . . . . 40

7. Future Plans for Services to Adolescent Mothers . . . . . 41 
CHAPTER I

SUMMARY AND RECOMMENDATIONS

INTRODUCTION

This needs assessment was conducted by 11 graduate students and their advisor from the Portland State University Graduate School of Social Work. The purpose was to determine the needs of adolescent mothers in Washington County and report the findings to the Washington County Task Force on Adolescent Pregnancy. Data for this needs assessment was compiled from three sources: social indicators (data), service providers, and target population responses.

Interviews were conducted with 34 service providers to determine the availability of services to the population. Questionnaires were distributed and 29 adolescent mothers responded regarding their perceived needs and services. The information in this summary is divided into the following areas: county-wide data; characteristics of the service providers and target populations; unmet service needs; and recommendations to improve services.

COUNTY-WIDE DATA

As of 1980, Washington County's population exceeded 245,000. Approximately 748 of these persons resided in the Tualatin Valley. This population figure shows an increase of $55.5 \%$ since 1970, making washington County the third fastest growing county in the state by percent, and first in terms of net increase in people. In 1978 there were 3,145 Chicanos 
residing within Washington County, representing 658 of the minority populaation for that county.

Approximately $80 \%$ of Washington County is considered rural, the bulk of which lies in the western part of the county at some distance from the urban center in the east. The two main population centers within the county are the cities of Beaverton (which is considered part of the Portland Metropolitan Area) and Hillsboro, the county seat.

The average adjusted gross family income in 1979 for Washington County $(\$ 16,768)$ and the median household income $(\$ 17,143)$ ranked highest of any county in oregon. In that same year, the per capita income was over $\$ 9,000$, ranking fourth highest of Oregon's 36 counties.

In 1970, Washington County had the lowest percentage of poor in the state. Nearly 10,000 people were reported living below the poverty level. In 1979, the county ranked fourth lowest in the state in percentage of people receiving public assistance. Unemployment in the county ranks third to the lowest according to 1979 figures, with 4,051 unemployed persons within the county.

Focusing specifically on the target population, accurate school "drop out" data is difficult to ascertain. In the last five years, an average of approximately 268 of the potential high school graduating class enrolled in the ninth grade failed to receive high school diplomas. This is an average withdrawal rate of about 6.58 a year. This percentage ranks lower than the state average of $8 \%$ per year. Of the females represented in the 268 withrrawal figure, it is estimated 11.48 will state pregnancy as the main reason for dropping out of school.

There were 3,822 live births in washington County in 1979, reflecting a birth rate of 17.5 per 1000 people. This figure is slightly higher than 
the state average of 16.3 . In keeping with the statewide and national trend, adolescents in Washington County comprise 328 of the total births to unwed mothers. Furthermore, adolescents represent the most dramatic increase in births to unwed mothers of all age groups.

Twice as many teenagers are seeking abortions statewide than ten years ago. It is estimated that 728 of these teens obtaining abortions did not have or use contraceptives. In addition, the age specific rate for abortions to girls 14 years and under has risen from 1.6 to 2.4 (per 1,000 females in the age group) since 1970.

\section{CHARACTERISTICS OF THE TARGET POPULATION}

Questionnaires were distributed to adolescents through three programs. They were: 1) County Public Health Department's "high risk" group and prenatal clinic; 2) Beaverton High School's "Continuing Education for Young Parents" class; and, 3) Virginia Garcia Clinic. Twenty-nine questionnaires were completed and returned between December 15, 1980, and January $31,1981$.

Of the 29 respondents, the modal age was 18, with the mean age being 16.7 years.

A majority of respondents (22 out of 29) described themselves as Caucasian. In addition, 22 reported being single and seven reported being married, with one out of the seven separated.

The respondents reported living in the following five cities: Hillsboro, Beaverton, Forest Grove, Aloha and Cornelius. Fourteen of the young women reported living with their parents. Seven listed their financial support as welfare, five from their husbands and five from their boyfriends. 
Most of the respondents (20) reported themselves as being in the low income brackets, earning less than $\$ 10,000$ a year.

Regarding the health of the 29 respondents, 15 listed they were pregnant at the time they answered the questionnaire, with one who was unsure of pregnancy. Of these pregnancies, four were planned. Twelve respondents were not pregnant. All respondents who were pregnant planned to keep their babies.

The questionnaire showed that 20 of the 29 respondents had been previously pregnant. Of these, nine were currently pregnant. Eleven of the 20 who were previously pregnant had kept their babies, two had abortions, two gave their babies up for adoption and three of them miscarried. Two of these three had miscarried twice. Of these 20 pregnancies, three were planned and 16 were unplanned.

Twenty-two of the $29 \mathrm{girls}$ surveyed reported receiving prenatal care. On the average, the respondents received prenatal care in the third month. All indicated that this care was obtained through a private doctor. It should be noted that because the majority of these responses came from the "high risk" group, it is difficult to determine whether the data on prenatal care is characteristic of the total population.

Out of the 11 who had already had a baby at the time the questionnaire was answered, ten said they had received postnatal care. All reported receiving this through a private physician.

When asked whether they had discontinued their education after their pregnancy, 12 said they had continued their education and 15 answered that they did not continue after becoming pregnant. Five reported they had already received a G.E.D. or high school diploma and four were in the process of obtaining one or the other. 
The fact that the schools have responsibility for providing their education was known by ten of the respondents. Sixteen indicated they were not informed of this.

Housing and financial aid were the top priorities wanted by the respondents both during and after pregnancy. On the other end of the continuum, abortion and adoption information were the lowest priorities both during and after pregnancy. Both job training and transportation were high priorities during pregnancy, but dropped somewhat after pregnancy.

The respondents reported that during pregnancy, nutritional guidance and birth control information were the services most often received. After pregnancy, few respondents indicated that they had received follow-up services. This lack of follow-up experience may be due to the respondents' not knowing what was meant by the term in the questionnaire rather than an unmet need.

\section{CHARACTERISTICS OF THE SERVICES}

A questionnaire was designed that requested information regarding services currently available to adolescent mothers. This was verbally administered to 34 service providers. These interviews were intended to determine what proportion adolescent mothers represent in the providers' total client population. Service providers were also asked to identify what services they thought were needed and to estimate what proportion of the agency's total population was adolescent mothers.

The 34 service providers included nine high schools, six health care and health education agencies, and four mental health agencies. Few agencies surveyed in Washington County listed services to adolescent mothers as their primary focus. Most of the agencies do not record the 
reasons their clients come to them. Several respondents estimated that adolescent mothers form $2 \%$ or less of their caseloads.

The respondents estimated that a majority of the adolescent mothers served were between the ages of 16 and 19. Twenty percent were between the ages of 12 and 15 , and 18 were younger than 12 years old. More than half of the clients seen by the service providers were estimated as low income. Nearly a third were listed as middle income and only $10 \%$ came from high incomes.

The service providers estimated that $73 \%$ of the adolescent mothers were Caucasian and nearly one-fourth (22\%) were Hispanic. Most clients were self-referred. Other referrals, in descending order, came from: friends, families, other agencies, and schools.

The most prevalent service available to adolescent mothers was counseling, which was offered at 28 of the 34 agencies represented. Of the services available, counseling and information/referral were used most often. Other services available at several agencies were: academic education, sex education, information and referral, and health/medical. Some services were available from only one agency in the county. Residential care, translation, adoption and outreach were available, but adolescent mothers had to go to a different agency for each service. Several agencies frequently exchange clients and coordinate services. The most frequently mentioned were: Washington County Health Department, Children's Services Division, individual physicians, Washington County Adult and Family Services, Virginia Garcia Health Center, Boys and Girls Aid, White Shield Home, and the W.I.C. Program.

When asked if they were aware of task forces, training or skillsharing, 18 respondents were aware of the Washington County Task Force on 
Adolescent Pregnancy, six were not aware of such services, and two mentioned the program at Virginia Garcia Clinic. Most agencies (24) had no waiting list for services. Seventeen of the 34 respondents said that adolescent mothers are identified as priority clients. Fourteen of the agencies do not put time limits on client contacts. Twelve agencies serve individuals for more than six months.

Respondents were asked to list obstacles to providing services. The difficulty listed most often was the lack of interagency coordination (11 responses). Several respondents described services as "hit or miss." Nine respondents list budget and legal constraints as obstacles. School personnel face obstacles of parental and community opposition to sex education and counseling dealing with sex-related issues. Other factors that were listed as obstacles to providing services were identified as characteristics of the adolescents themselves. For example, the need to remain anonymous and self-image concerns were mentioned. Twenty-eight respondents said that follow up is available from their agencies; however, only 12 respondents listed specific follow-up services such as referrals to community health nurses and counseling.

When questioned regarding what changes would improve the coordination of services, 22 respondents suggested linkages between agencies. Respondents specifically mentioned the need for better communication between agencies and schools; continuity of care; more contact with school counselors; and increasing awareness of community resources.

Respondents were asked if they thought the services to adolescent mothers were sufficient. Twenty-nine of the 34 people said that they did not think services were sufficient. Almost one-third said more services 
need to be provided through the educational system because the schools have the most contact with adolescents.

\section{UNMET SERVICE NEEDS}

Adolescent mothers in Washington County have a number of social, health, and economic needs which are not being met through the existing service delivery system. These unmet needs are exacerbated by the fact that programs for this population are not mandated by either the federal, state, or county governments. Although teen pregnancy has long been acknowledged as a national problem, funds for local professionals to implement educational and support programs are virtually non-existant. Indicative of this lack of resources is the failure of Oregon's school districts to collect data on teens who terminate their education because of pregnancy. This lack of adequate school withdrawal statistics makes the task of identifying and serving adolescent mothers extremely difficult. Pregnant and parenting adolescents in Washington County have difficulty in locating and utilizing services because there is no one centralized source that offers a comprehensive program. Consequently, the programs that do exist, such as W.I.C., Virginia Garcia Clinic, and the Beaverton School District's Continuing Education for Young Parents, have become strained, both in terms of fiscal viability and administrative capacity.

Results of the service provider and target population surveys suggest that most pregnant adolescents in Washington County who choose to keep their babies do not continue their formal education. The survey further revealed that most adolescent mothers are not aware of the school's responsibility to provide tutoring through Oregon's "handicapped" law. 
This lack of special educational programs in the schools is regarded as a major unmet need, especially in light of the other economic and health risks that face adolescent mothers.

Many of the pregnant and parenting adolescents in Washington County are unable to utilize existing services because of inadequate public transportation. This problem is compounded by the fact that most service providers are clustered in the Hillsboro area, which is often inaccessible to those in the outlying areas of the county.

Comprehensive information and referral services are essential to ensure service provision to adolescent mothers. However, the survey revealed that information and referral is often incomplete and unreliable. Other unmet needs voiced by both service providers and the adolescent mothers include:

-low cost and accessible child care;

-job training and career counseling;

-low cost delivery and hospital care;

-outreach and casefinding;

-housing alternatives;

-financial assistance;

-peer support groups for both adolescents and their families; and -follow-up services (except through Public Health Department). One of the major contributors to the aforementioned service gaps is the lack of interagency coordination among service providers in washington County. Service providers report that this lack of linkage prevents many agencies from sharing needed information, resources, and referrals. As a consequence, services are often "hit or miss" and 
follow up to adolescents who have received some services are wholly inadequate. Although half of the service providers interviewed were aware of the Washington County Task Force on Adolescent Pregnancy, the need for cooperative interagency programs is strikingly clear.

\section{RECOMMENDATIONS}

The authors of this study make the following recommendations for service improvement to pregnant and parenting adolescents in Washington County:

1) Increase interagency linkages and networking through information-sharing activities such as workshops, and ongoing communication between agency personnel. The Task Force may want to coordinate these activities and thereby become more visible within the county.

2) Compile a directory of services to adolescent mothers and their families in Washington County. This directory should be made available to service providers, educators, and adolescents. It may be possible to distribute these through the schools.

3) Establish one agency as a clearinghouse for information on services to the target population. This agency can act as a centralized source of information and referral for schools, health providers, and families.

4) Develop transportation alternatives for those adolescents in rural areas seeking services. This project may be coordinated with the county's youth service centers. 
5) Increase the involvement of school personnel in keeping pregnant and parenting teenagers in the educational system. Develop alternative educational programs (modeled after the Beavertor, School's program) which include information on parenting, support groups, nutritional guidance and sex education.

6) Advocate and establish opportunities for low cost delivery, health care, pre and post natal care. Establish contact with hospitals and involve them in the provision of services.

7) Establish programs of career counseling, budget/financial management, and legal counseling as opposed to traditional insight therapy.

8) Establish formal "follow up" procedures for adolescents who have received services. Define "follow up" and hold workshops for service providers concerning this issue.

9) Advocate and lobby for the recognition of the target population by state and local funding sources. This is particularly important in light of the current fiscal cutbacks in human resource and health programs. Coordinate lobbying efforts with the Oregon State Task Force on Adolescent Pregnancy. Attempt strong interim lobbying and bill preparation for state legislature. 
CHAPTER II

DEMOGRAPHIC DESCRIPTION OF WASHINGTON COUNTY

INTRODUCTION

This chapter is divided into three sections. The first, "Overview of Washington County," provides a general description of the county's physical characteristics and population distribution. The second, "Socioeconomic Indicators," reports selected statistics and trends such as income, housing quality, and educational status which generally reflect the overall social and economic conditions within Washington county. The third, "Health and Vital Statistics," presents health-related statistics including birth rates and abortion data for both Washington County and the state as a whole. Figures are presented within the sections as appropriate. "Highlighted Findings," "Methodology," and "Limitations" precede these sections.

\section{HIGHLIGHTED FINDINGS}

1) As of 1980, Washington County's population exceeded 245,000. Roughly 748 of these persons resided in Tualatin Valley in the eastern part of the county.

2) The county population has increased $55.5 \%$ since 1970 , making Washington County the third fastest growing county in the state by percentage of increase. It is first in terms of net increase in people. 
3) Washington County is substantially Caucasian; however, there are 3,145 Chicanos who represent $65 \%$ of the minority population.

4) In 1979, the average adjusted family gross income and median household income ranked highest in the state.

5) In 1970, nearly 10,000 people living below the poverty level represented the smallest county percentage of poor in the state.

6) Accurate drop-out data is very difficult to obtain, but it appears that the county's annual withdrawal rate of $6.5 \%$ is low compared to the state average of $8 \%$ per year. It is estimated that $11.4 \%$ of all females who drop out of school do so because of pregnancy.

7) There were 3,882 live births in Washington County in 1979 . of these, 340 were to adolescent mothers (19 years and younger).

8) In 1979, adolescents comprised 328 of the total births to unwed mothers in the county.

9) The rate of abortions to adolescents statewide (abortions per 1,000 females in the age group) has nearly doubled since 1970 with only $11 \%$ more teens in the population.

10) Statewide, 728 of the teens obtaining abortions did not use contraceptives.

11) In $1979,7.18$ of all births to adolescents statewide were immature (2500 grams or less). This figure decreases as the age of the mother increases. Over $5 \%$ of the births to women 
20-24 years were immature, and $4.5 \%$ of all births to women 25-29 were immature.

\section{METHODOLOGY}

The objective of this chapter was to provide descriptive statistics from which inferences about the service needs of adolescent mothers in Washington County could be determined. Various socio-economic, health, geographical, and demographic variables were selected that were considered to be appropriate indicators consistent with this objective. Statistical data representing these social indicators were then collected from public records and reports. The analysis and presentation of the findings are offered in the form of a descriptive summary.

\section{LIMITATIONS}

The underlying assumption of any social indicator approach to needs assessment is that useful estimates of need can be determined by examining statistics that are found to be correlated with persons in need. ${ }^{1}$ Thus, a general limitation of this section is theoretical in that the selected indicators are "soft" or indirect measures of the needs they represent.

Another general limitation has to do with the integrity of the collected statistics themselves. Since the social indicator approach to needs assessment relies on statistics found in various public records and reports, it is limited to and dependent on the accuracy and completeness of these data.

Specifically, this needs assessment has been conducted at a time when very little of the 1980 census data has been released. This means 
that for those indicators such as poverty level and educational attainment, we have been restricted to 1970 census data or estimates based on 1970 census data. This is especially unfortunate when considering washington County's rapid rate of growth.

Another example is the enrollment and withdrawal data kept by the county for the state Department of Education. The School Finance and Data Information Services at the State Department of Education reports that the data they collect is quite strictly related to that information which is necessary for determining funding subsidies and budgets. Thus, other information such as sex of student, minority enrollment, or type of withdrawal and reasons given are not routinely documented.

The absence of this record keeping has, in fact, posed this study with one of its most difficult problems and, consequently, one of its more serious limitations. Without knowing the sex of the students enrolled in grades six through 12 , we are unable to obtain what would be the most accurate estimate of the potential target population. Not knowing the reasons why students withdraw or "drop-out" of school, we cannot offer "hard" data regarding the number of adolescents who have dropped-out of school due to pregnancy. Perhaps a more serious limitation is imposed upon the schools themselves by having this information unavailable at a point of institutional interface where it might be used proactively for the well-being and continued education of the students.

\section{OVERVIEW OF WASHINGTON COUNTY}

Washington County (population 245,633$)^{2}$ encompasses a unique blend of urban and rural areas. Its geographic setting accounts for this 
diversity and provides natural population boundaries. Washington County is located west of the city limits of Portland, with the Tualatin Mountains forming the county's eastern border. To the north are Columbia and Clatsop Counties with Tillamook County and the costal range comprising the western border. Yamhill and Clackamas Counties are located to the south. In total, Washington County contains approximately 716 square miles.

The majority of Washington County's population resides within the Tualatin Valley, which includes the cities of Beaverton, Tigard and Tualatin. According to the Portland State University Center for Population Research and Census, 748 of the county's total population lives within this valley.

Extending north and westward of this valley is the rural area of Washington County. Of this region, $80 \%$ is considered rural and the main cities include Hillsboro (county seat), ForestGrove to the west, and Banks to the northwest. The topography of this rural region is mainly comprised of the forest areas of the coastal and Chehalem mountain ranges.

Perhaps one of the most significant characteristics of Washington County, besides its economic and geographic diversity, is its growth in population over the last ten years. Figure 1, shown below, gives washington County Population, 1975-80. Since 1970, Washington County's population has increased by 88,000 persons, which is an increase of 55.58 , according to the Census Bureau's preliminary report for 1980. This makes Washington County the third fastest growing county in Oregon in terms of percentage of increase. It should be noted, however, that this increase is due primarily to net immigration, rather than an increase in the birth rate. 


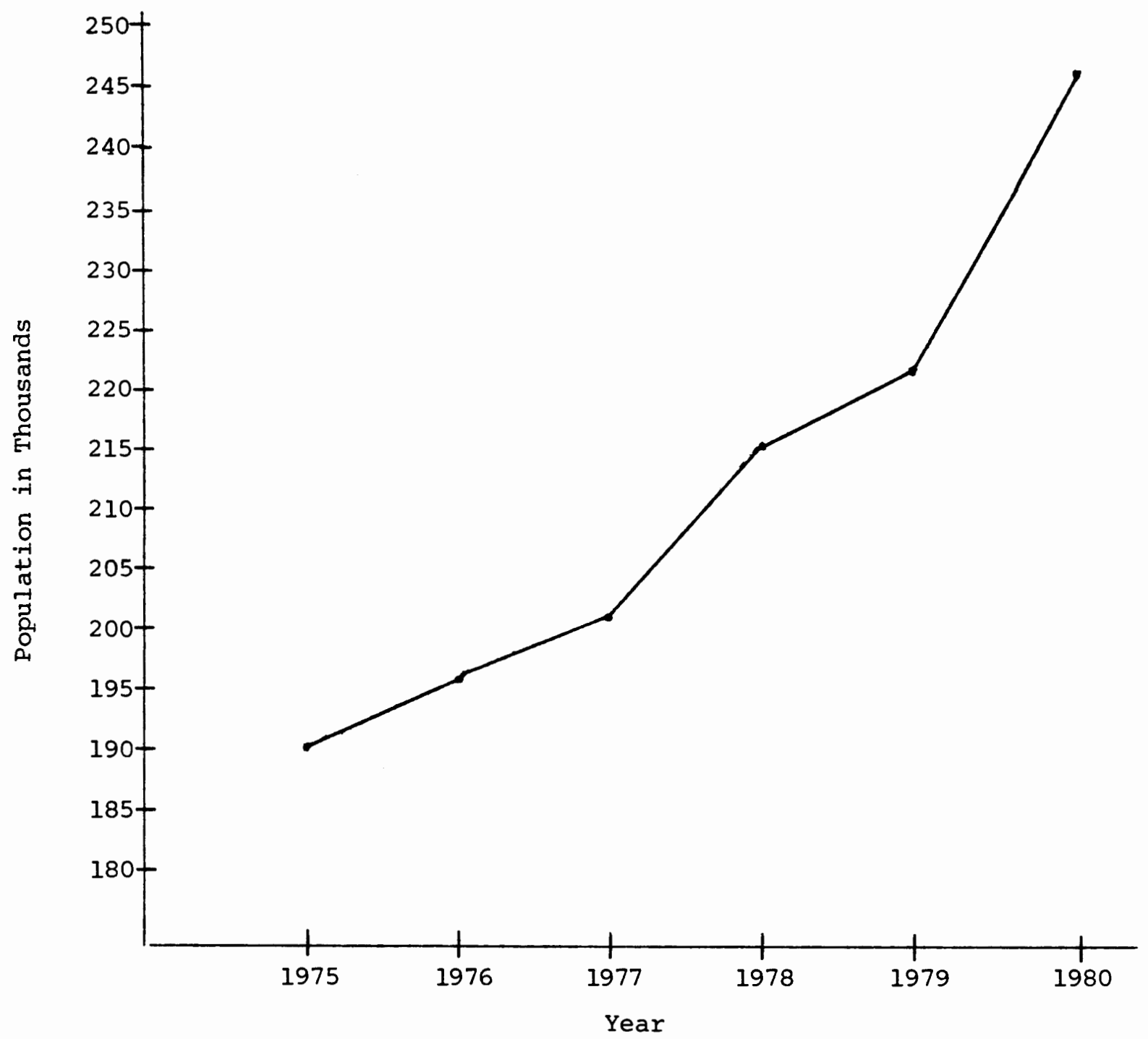

Figure 1. Washington County Population, 1975-1980.

Source: Population estimates from Center for Population Research and Census, Portland State University, except for 1980 figure, which is a preliminary figure from 1980 U.S. Census.

The 1978 County population distribution indicates that there were approximately 38,000 people in washington County between the ages of 10 and 19. This represents a 3.68 increase since $1977 .^{3}$

The ethnic composition of the Washington County population is primarily Caucasian. The settled Chicano community of 3,145 (1.68 of the 
total county population), represents $65 \%$ of the minority population. Blacks, Native Americans, and Asians combined represent less than 18 of the county population. ${ }^{4}$ However, the recent influx of Indochinese into the Portland Metropolitan Area is influencing the ethnic distribution in Washington County, although exact figures are not available at this time.

\section{SOCIO-ECONOMIC INDICATORS}

Income

The latest economic statistics for Washington County indicate that, relative to the rest of Oregon, the county is among the wealthiest in the state. The average adjusted gross income for Washington County families in 1979 was $\$ 16,768$ and the median family income was $\$ 17,184 .^{5}$ These figures for Washington County are the highest of any of Oregon's 36 counties. In terms of per capita income, Washington county ranks fourth in the state with a 1979 average of $\$ 9,075$, which is above the state average of $\$ 8,074 .^{6}$

According to the 1970 Census, 9,876 Washington County residents were living below the poverty level. This represents 4.28 of the state's total number of poor $(234,808)$. Washington County had the lowest percentage (6.38) of poor people among the state's 36 counties in 1970 .

According to the Department of Human Resource's 1980 Socio-economic Indicators, Washington County had a low percentage of residents receiving various forms of public assistance. Out of 36 counties, Washington County was ranked $32 \mathrm{nd}$ in the number of persons receiving Aid to Dependent Children $(A D C)$, with a total of 2.38 of the county population on welfare. Adult and Family Services Division of the State Department of Human Resources reported that in 1979, the monthly average of ADC cases in Washington County 
was 1,855 and the monthly average of persons was 5,143. Among other assistance categories, the monthly averages of total recipients (in 1978) were: Social Security, 831; General Assistance, 156; and Food Stamps, 7,174.

In 1979, there were 4,051 unemployed persons in Washington County. While the total number of unemployed persons is sixth highest in the state, Washington County ranks third from the lowest in percentage of total population which is unemployed $(4.48) .^{7}$

$\underline{\text { Housing }}$

In 1979, the percentage of substandard housing, defined as the number of dwellings built prior to 1939 , was 8.28 for the county. When compared with other Oregon counties, Washington County had the lowest percentage of substandard housing. Reflecting the county's recent growth, it also ranked first in number of building permits issued in $1979 .^{8}$

\section{Education}

The 1970 Census reported that washington County adults, 25 years and older, have generally received more education than their statewide counterparts, with 71.78 who have finished high school, as compared to a state average of $60 \%$. In this category, Washington County ranks second only to Benton County. Figures from 1979 indicated that over the last five years, an average of 748 of Washington County ninth graders finished high school with their class. 9 This is slightly higher than the five year state average of $70.5 \%$. 10 within this same adult population (25 years and older), $17 \%$ had completed one to three years of college, and 178 had completed four or more years of college. The median school years for this population was 12.6 years. 11 
In 1978 , there were 24,040 students age seven through 13 and 15,986 students ages 14 through 19 enrolled in school in washington county. 12 The 1970 Census indicated that about $99.1 \%$ of the persons ages 14 through 17 were enrolled in school in Washington County. Further, 89.58 of the persons 18 years and younger were living with both parents. 13

Two years later, in 1980, the school enrollment in washington County for kindergarten through 12 th grade was nearly $46,800 .^{14}$ Relative to the target population of this needs assessment (adolescent females 19 years and younger), there were nearly 26,000 persons enrolled in school between grades six and 12.15

While it might be assumed that roughly 508 (or just over 13,000) of these students were female, an accurate breakdown by sex is virtually impossible to obtain since neither the State Department of Education nor the county maintain these statistics. The State Department of Education does report, however, that 7,000 washington County students withdrew from school in the 1979-80 school year. Because statistics are not maintained as to the reason for withdrawals, there is no way to determine which students "dropped out" due to transfers, early graduation, promotions, or for other reasons such as pregnancy.

The 1980 Oregon Early School Leavers Study, conducted by the Oregon Department of Education, represents a survey of 54 secondary schools in oregon. 16 Interviews were conducted with 529 students who left school during the 1979-80 school year (52.8\% males and $46.4 \%$ females). One-third of these left school during their junior year. Pregnancy was listed as the reason for leaving by 11.48 of females. The researchers observed that: Differences between the responses of males and females appear to center around stereo-typical sex roles. Females had higher 
response rates for marriage, pregnancy, illness, doing nothing, or leaving to help with family or financial problems. 17

Overall, the study indicated that $32 \%$ of the potential graduating class enrolled in the ninth grade would leave school prior to the end of their senior year without receiving diplomas. Again, however, the definition of "early leaver" used in this study did not preclude transfers from being represented.

In Washington County, $26 \%$ of the potential graduating class dropped out during the four year period between $1979-79 .{ }^{18}$ This represents a $6.5 \%$ per year withdrawal rate.

HEALTH AND VITAL STATISTICS

\section{Iive Births}

According to the Oregon State Health Division Vital Statistics Section, there were 41,564 total live births in Oregon in 1979. In Washington County there were 3,882 live births in the same year. The birth rate (number of live births per 1,000 population) was 17.5 , which was slightly higher than the state figure for 1979 (16.3). In the past five years, the live birth rate for both oregon and Washington County has remained fairly stable. Figure 2 shows the live births in Washington County.

\section{Live Births to Adolescents}

Of the 3,882 live births in Washington County in 1979,340 of these were to adolescents 19 years or younger. ${ }^{19}$ This figure represents approximately $9 \%$ of the total county births and is lower than the statewide average for adolescent births which was $13.3 \%$ for 1979 . The majority (90\%) of births to washington County adolescents was in the 17 through 19 
year age group. There were, however, 33 births to adolescents in the 13 through 16 year age group. 20

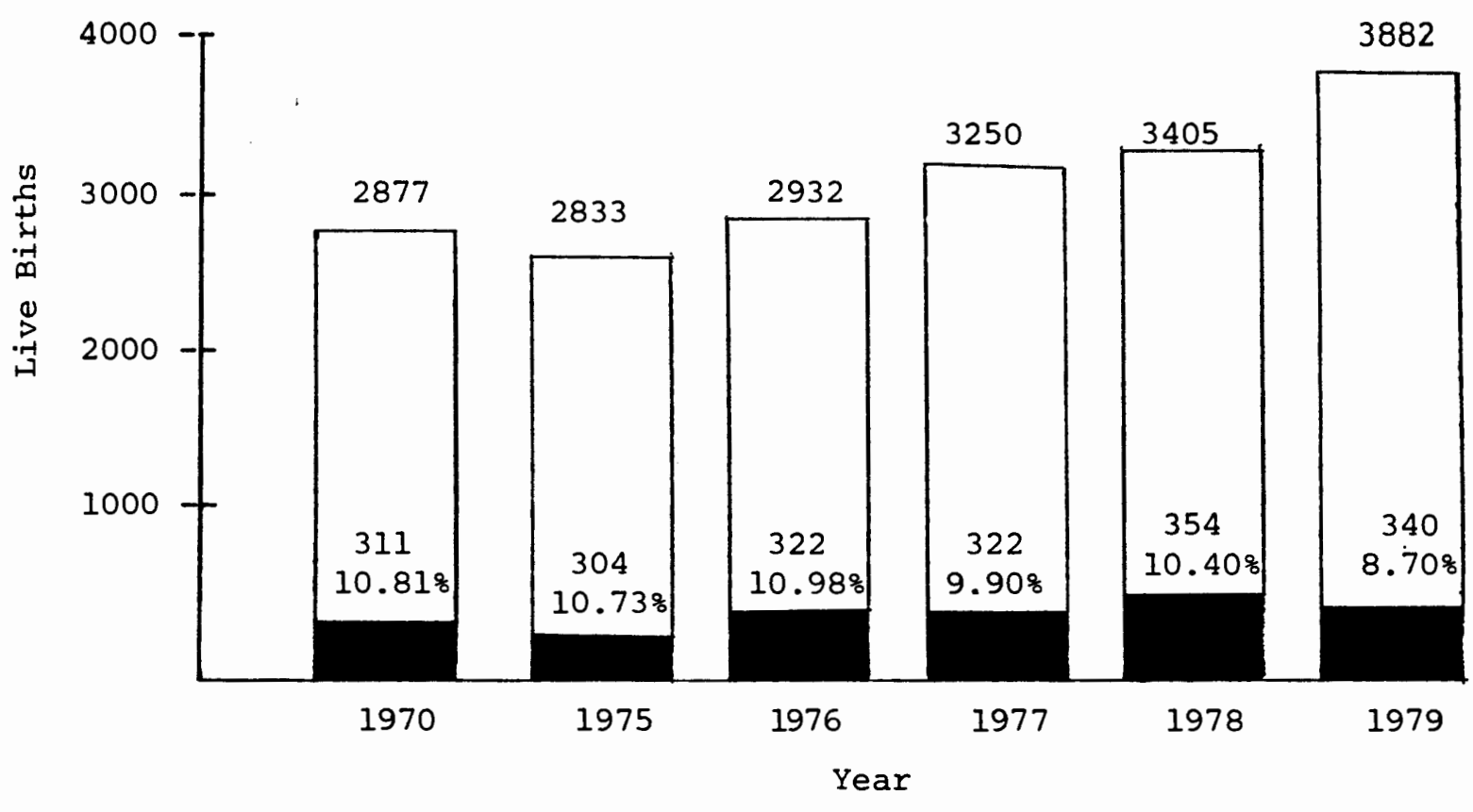

$\square=$ Total Live Births

= Adolescent Live Births (19 years of age and under)

Figure 2. Live births in Washington County. Source: Oregon Public Health Statistics Reports for Calendar Years 1970-1979.

\section{Adolescents as Unwed Mothers}

Teenagers are over-represented among births to unwed mothers in that they comprise 328 of the total 311 births to unwed mothers of all ages in Washington County. This is slightly below the 1979 state figure of $408 .^{21}$ These figures support the statewide trend which reflects an increase in the number of unwed mothers in all age groups in recent years. Figure 3 , shown below, shows unwed births to adolescents in Washington County. Additional statistics to this section may be found in tables in Appendix $B$. 


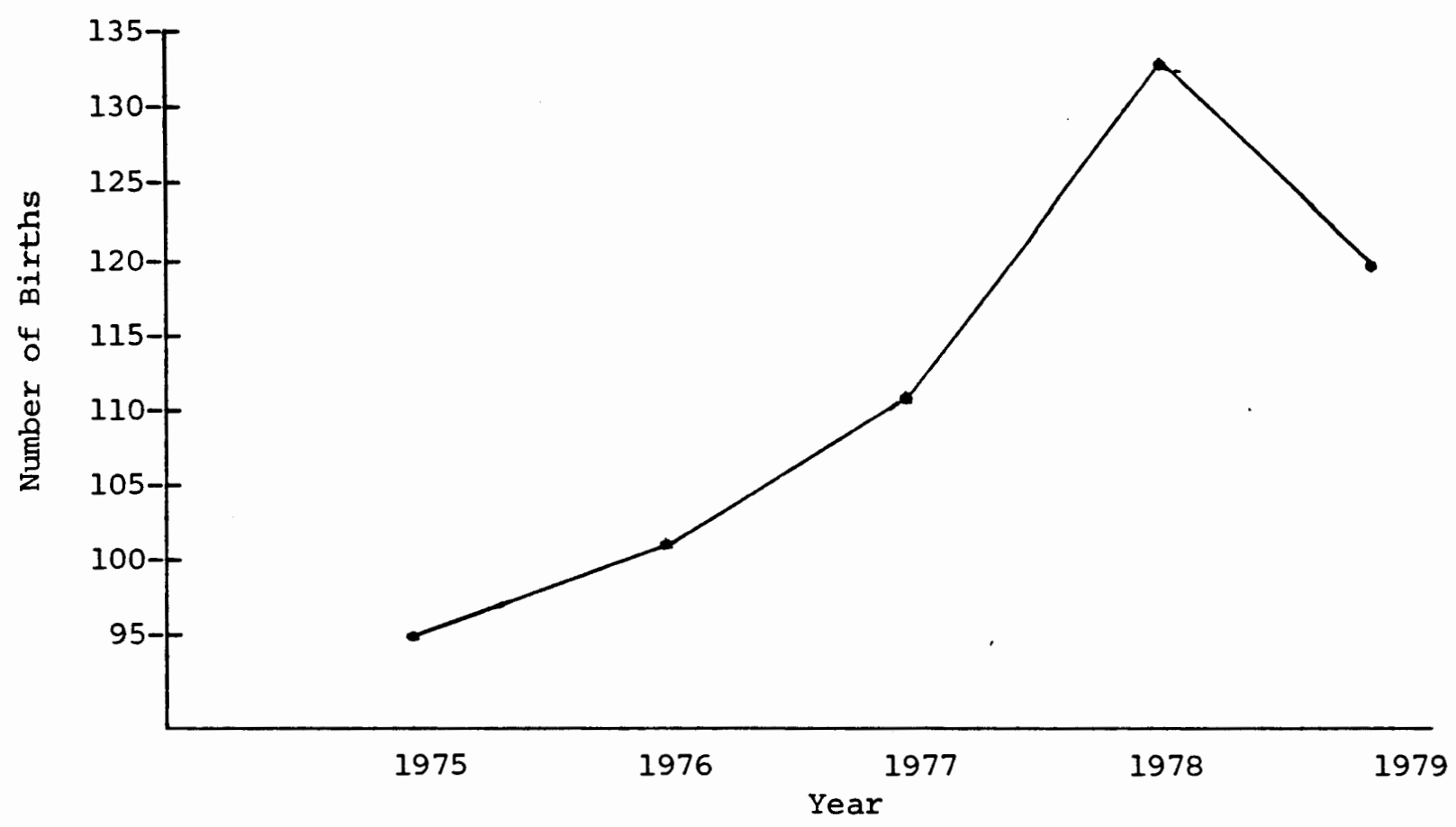

Figure 3. Unwed births to adolescents (19 years of age and under) in Washington County. Source: Oregon Public Health Statistics Reports for Calendar Years 1975-1979.

\section{Abortions}

In the decade that has passed since the Oregon Legislature liberalized the abortion laws, the number of induced abortions has risen from 7,187 in 1970 to 14,501 in $1979 .^{22}$ This trend has also held for the younger population, with twice as many adolescents seeking abortions statewide than were ten years ago with only 118 more teens in the population. 23 This trend is reflected in Washington County data. Of the 986 induced abortions to Washington County residents in 1979, 378 (369) were to adolescents, as shown in Figure 4, below. This is slightly higher than the state figure of 338 and the Multnomah County figure of 30\%. 24 In the 15 through 19 age group, this rate (per 1,000 live births) has risen from 23.4 in 1970 to 41.4 in 1979. Statewide, 728 of the adolescents obtaining abortions did not have or use contraceptives. 25 Ninety-three percent of the teenagers who 
obtained abortions were not married. Perhaps the most significant figure is that the age-specific rate (per 1,000 female population with age group) for abortions to those in the under 15 year group has risen from 1.6 to 2.4 since 1970.26
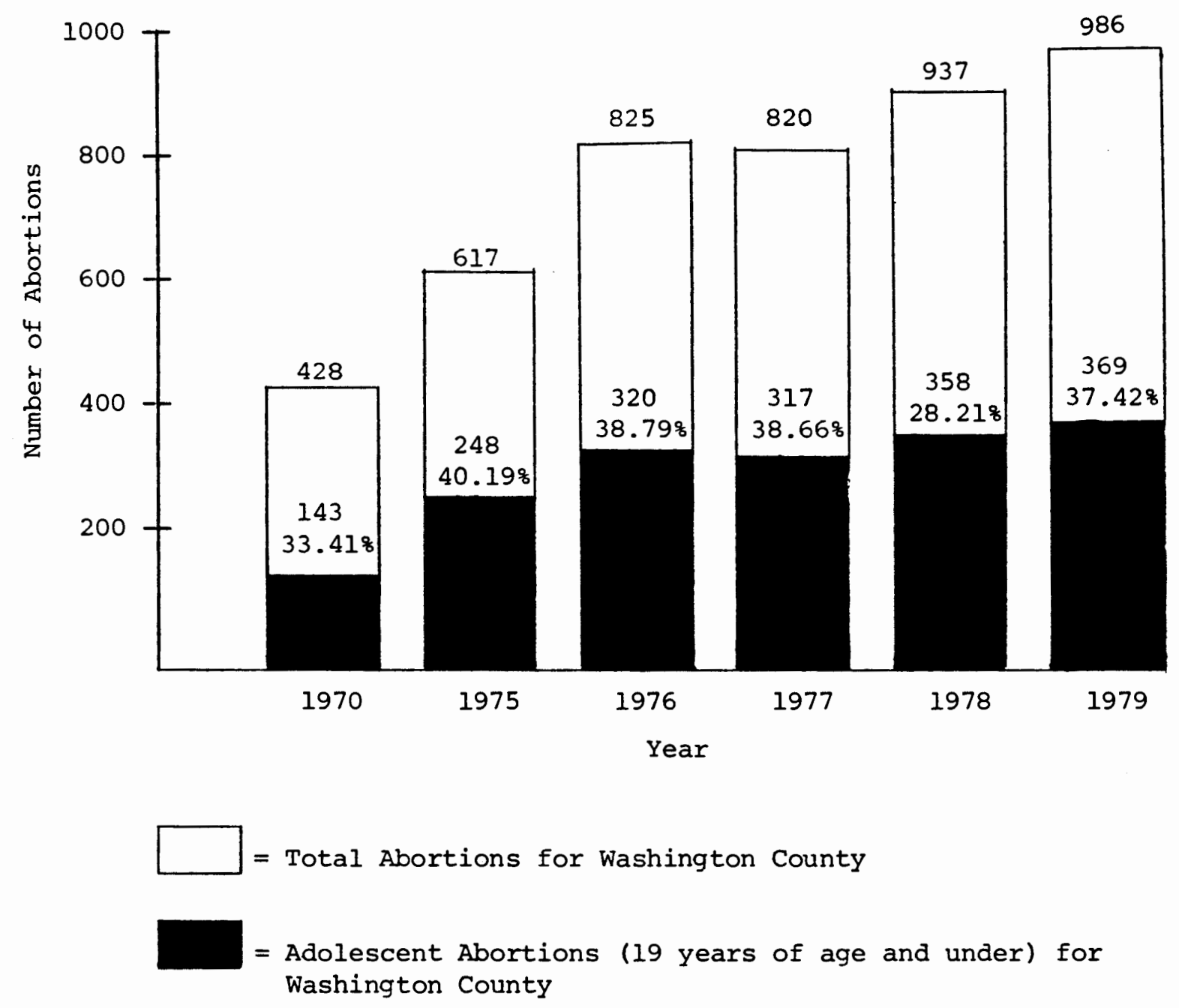

Figure 4. Abortions in Washington County. Source: Oregon Public Health Statistics Reports for Calendar Years 1970-1979.

\section{Immature Births}

One of the possible difficulties that adolescent mothers face is the increased risk of immature births (less than 2500 grams or 5.8 lbs.). Statewide the statistics reveal that 7.18 of all teenage births in 1979 
were immature. This figure markedly decreases as the age of the mother increases. Of the births to women 20 through 24 years of age, 5.3\% were immature and $4.5 \%$ of all births in the 25 through 29 age group were immature. 27 
CHAPTER III

CHARACTERISTICS OF THE SERVICE PROVIDERS

INTRODUCTION

The purpose of this part of the needs assessment was to obtain current information from service providers about the kinds of services presently available to adolescent mothers; services needed but unavailable; the number of adolescent mothers offered or receiving services in comparison to the agencies' total client population; and the providers' future plans for delivery of services to adolescent mothers in Washington County.

This chapter has been divided into six main sections.

Section I describes the methodology of collecting the data.

Section II presents the characteristics of service providers interviewed.

Section III describes the clients served.

Section IV addresses those services available to adolescent mothers in Washington County.

Section $\mathrm{V}$ discusses interagency linkages.

Section VI presents agency philosophy toward the adolescent mother and agency funding sources.

METHODOLOGY

The respondents (service providers) represented 34 programs in the following areas: education, health, juvenile justice, counseling, 
financial, employment, and child care. They were selected from a list of agencies suggested by the Washington County Task Force on Adolescent Pregnancy. This list was later expanded by recommendations from professionals in Washington County who work closely with adolescent mothers. Eight providers in the Portland area were included since they provided services to Washington County residents which are not available within the boundaries of Washington County.

A 32-item questionnaire was developed which covered both closed and open ended questions. (See the Appendix for a copy of the questionnaire.) In early December, 1980, a letter was sent to all respondents, under the auspices of the Washington County Task Force on Adolescent Pregnancy, notifying them of the needs assessment. Interviews, lasting one to oneand-a-half hours, were conducted during the last two weeks of December, 1980, and the first week of January, 1981. All the interviews were conducted on a face-to-face basis, with the exception of two interviews which were conducted by telephone.

\section{LIMITATIONS}

One purpose of the survey was to estimate the number of adolescent mothers who had actually received services in Washington County. Unfortunately, this was not possible. Many service providers interviewed do not keep records of actual numbers of adolescent mothers. In 26 of the 34 agencies represented, the percentage of adolescent mothers to total clientele was less than 28. There was no way to determine whether this was an unduplicated count of clients, since it was not possible to establish if adolescent mothers were receiving services from more than one agency and were, therefore, being counted more than once. 
It was decided not to interview private doctors or junior high school counselors. Approximately 208 of the adolescent mothers were in the lower age group (15 years and younger) in the school population, so this may have been an oversight.

This report was intended as a descriptive survey of services available to adolescent mothers. The answers given may not represent the agencies' viewpoints, but reflect the opinions and daily experiences of the respondents. The Numbers given are often general estimates which provide information for comparison.

\section{CHARACTERISTICS OF SERVICE PROVIDERS INTERVIEWED}

Thirty-four agencies providing services to, or having contact with, adolescent mothers, were selected for interviews. Several different types of organizations were included in an effort to insure that no field of service to adolescent mothers was overlooked. The types of organizations were: educational, public and private social service agencies, juvenile justice, and health service agencies. Twelve agencies' respondents stated their agency provided more than one type of service.

Refer to Table $\mathrm{X}$ in Appendix $\mathrm{B}$ for $\mathrm{a}$ list of the names and addresses of agencies included in the survey, catchment areas, and services provided.

The service or catchment area of 15 of the agencies was Washington County. Twelve organizations reported their service area as a school district, while two agencies provided service only to the city in which they ( were located. Four agencies provide service statewide. Two agencies serve Washington, Clackamas, and Multnomah Counties. Two agencies provided service to the surrounding four-county area. Once agency provided services to Oregon residents as well as to out-of-state referrals. 
Thirteen agencies (30\%) had offices in Hillsboro, although the population of the county lies primarily in the Beaverton Area. Eight agencies providing services to Washington County residents were located outside (east of) the county, in the Portland Metropolitan Area. Of the five agencies located west of Hillsboro, three were school districts. No agency offices were found to be located west of Forest Grove in Western Washington County. (See map in Appendix B.)

\section{TABLE I}

NUMBER OF SERVICE PROVIDERS, BY AREA

Location

$$
\text { Hillsboro }
$$

Beaverton

Portland

Aloha

Forest Grove

Cornelius

Tigard

Banks

Gaston

Sherwood

Total agencies surveyed
No. of Service Providers

13

4

8

1

2

1

2

1

1

1

The size of professional staff varied greatly from agency to agency and was very difficult to measure. When asked how large their professional staff was and how many work with adolescent mothers, responses varied due to interpretation of the question. Some of the respondents noted that all their professional staff were qualified to work with adolescent mothers, 
while other respondents counted only those staff actually working with the target population.

\section{CLIENTS SERVED}

Findings in this section focused upon the adolescent mothers within the total clientele of the service providers. The numbers are based on estimates given by respondents interviewed. Many of the respondents were uncomfortable making these estimates. Six of the 34 respondents estimated that 258 of their agencies' caseloads was adolescent mothers. Sixteen respondents estimated agency caseloads of less than 28 adolescent mothers.

Respondents were asked to estimate the ages of adolescent mothers served. Seventy-eight percent of the adolescent mothers served were between the ages of 16 and 19; $20 \%$ were between the ages of 12 and 15 ; and $1 \%$ was less than 12 years old.

Respondents estimated over half (62\%) of the adolescent mothers served had low incomes $(\$ 10,000$ and below). Nearly one-third (27\%) had middle incomes $(\$ 10,000$ to $\$ 20,000)$, and $10 \%$ had or resided with families having high incomes $(\$ 20,000$ and above).

Estimates of adolescent mothers served according to ethnic background were as follows: $73 \%$ Caucasian, 228 Hispanic, 48 Asian, .38 Black, .18 Native American, and .05\% other.

When asked if they were aware of the number of adolescent women who became pregnant in 1979, four of the 34 respondents were aware of the official Washington county statistic of $709 .{ }^{28}$

Of the agencies contacted, 15 respondents said they had no contact with the fathers of the babies. Nineteen respondents estimated some contact 
with the fathers. Of these 19 agencies, three work with $33 \%$ of the fathers, 15 work with 1-158 of the fathers, and one estimated having contact with 508 of the fathers.

Respondents were asked how adolescent mothers were referred to them. The following chart demonstrates the source of referral and number of responses.

TABLE II

REFERRAL SOURCES

\begin{tabular}{lc}
\hline Source of Referral & No. of Responses \\
\hline Self & 26 \\
Friend & 24 \\
Family & 21 \\
Other Agencies & 20 \\
School & 20 \\
Newspaper/Media & 4 \\
Physicians/Nurses & 4 \\
Former Clients & 1 \\
Police & 1 \\
Court & 1 \\
\hline
\end{tabular}

Total Responses $=122$

SERVICES AVAIIABLE TO ADOLESCENT MOTHERS

Respondents were asked what services for adolescent mothers were available through their agencies. Counseling services were most frequently 
offered. The following table lists services provided and the number of agencies offering the service.

TABLE III

SERVICES AVAILABLE

Service

No. of Agencies Offering Service

Counseling

Sex Education

Academic Education

Residential Care

Health/Medical

Financial

Employment

Information/Referral

Advocacy

Other

\section{8}

13

14

1

11

3

8

12

4.

5

The other services offered were adoption, transportation, translation, little brother/little sister, and outreach.

When asked if their agency had a waiting list, 24 of the 34 respondents said there was no waiting time for services. Two agencies had a one-week waiting period and two other agencies had a two-month waiting period. The longest waiting period for service was six months, which was recorded by two respondents.

When asked if services to adolescent mothers are a priority for their agency, 17 of the respondents stated that adolescent mothers were priority clients. Thirteen respondents said such services were not a priority. Four respondents gave no answer. 
In response to the question regarding how long the agency kept contact with the adolescent mothers, 14 respondents said their services were not time limited. Six respondents stated their agency maintained contact with adolescent mothers for about six months. Four respondents said one year. Other responses were, "up to three months" (two responses), "more than one year" (two responses), "one contact" (one response), and "one month" (one response). Four respondents said although they have contact with other professionals working with adolescent mothers, they had no contact with the target population.

When asked whether or not follow-up services were available to adolescent mothers, 28 respondents stated, "Yes, follow-up services are available." of these 28 respondents, 12 actually listed what follow-up services were currently available. The follow-up services named were: referral to community health nurse (five responses), counseling (five responses), education/ home study (two responses), follow-up letter (two responses) and residential care (one response).

Respondents were asked what service offered to adolescent mothers was used most often. The following table lists the services utilized most.

TABLE IV

SERVICES USED MOST OFTEN BY ADOLESCENT MOTHERS

\begin{tabular}{lc}
\multicolumn{1}{c}{ Services } & No. of Responses \\
\hline Information/Referral & 12 \\
Counseling & 11 \\
Pregnancy Education & 7 \\
Academic Education & 6 \\
Health/Medical Care & 6 \\
Financial Aid & 2 \\
Adolescent Mothers Group & Total Responses \\
\hline
\end{tabular}


Respondents were asked to list specific obstacles to providing services for adolescent mothers. One agency attempted twice in the past year to set up a support group for adolescent mothers - a service that several agencies had given as a priority; however, an insufficient number of referrals prevented them from starting the group. The most frequent obstacle given by 11 respondents was the apparent lack of interagency communication and contact. Lack of money and "legal criteria" both had nine responses. Eight respondents listed the issue of "confidentiality" and the extent one can counsel pregnant teenagers without involving their parents. One school counselor discussed the issue of being willing to do more counseling except for the threat of parents "breaking the office door down." Several counselors noted there were real confidentiality and liability issues at stake, particularly in the area of "abortion" counseling. Four respondents cited the difficulty of locating clients as a problem. Lack of staff time was given as a factor for not becoming more involved in the Task Force on Adolescent Pregnancy. Several requests were made for training sessions and workshops on adolescent pregnancy to be offered in Washington County rather than in the Portland area. Three respondents felt that "characteristic factors within the personality of the adolescent mother herself" were an obstacle to providing more extensive services. Two counselors noted "the pregnant teenager demands anonymity"; one added the reason she drops out of school is "not that she is ostracized by teachers or other students but because she no longer feels part of the program." Several respondents felt pregnant teenagers dropped out of view because of self-image problems rather than because of stigma. The statement that services to adolescent mothers represented a "hit and miss" activity came up in seven interviews. 
One counselor thought there was a real need for a consistent contact person the young mother can trust.

Other responses to the question of obstacles to providing services were:

1) "Lack of funding, we don't have a statistical data base with which to identify the need."

2) "Location of agency, it's hard to get there by public transportation."

3) "It has to be a co-ordinated effort."

4) "Confidentiality--obligation to parents; it's a 'Catch-22' situation."

5) "We have a ridiculous amount of paperwork."

6) "There is no outreach--these girls are isolated by our society."

7) "No funds are budgeted specifically for services to adolescent mothers."

8) "There are so few prevention programs--we wait until there is a problem and try to fix it..."

9) "Our caseloads are so high it's hard to give any of our clients adequate services."

10) "For people in Western Washington County, services in Portland are unrealistic. Portland is a real scary place for many Western Washington County residents."

11) "Educational services--the schools have a legal obligation to provide adolescent mothers with educational opportunities." 12) "Many families are resistant to outside help." When asked what specific changes should be made to improve the coordination of services for adolescent mothers, 22 respondents requested 
improved interagency linkages and a better means of informing other agencies of the services each agency provides for the adolescent mother. One respondent stated there was a need to "try to co-ordinate the services we are aware of to get the maximum help to the adolescents in need."

Several common responses were:

1) "Better communication between agencies and schools."

2) "Educational and nutritional services should be followed through and coordinated."

3) "Agencies should have more contact with school counselors."

4) "Our agency'needs to place adolescent mothers on a higher priority."

5) "Staffing procedures need to be improved between agencies."

6) "Awareness of the problem is lacking."

7) "Increase the awareness of our agency's existence."

8) "There is no listing of what services are available."

9) "There should be more collaboration between agencies and less advice-giving."

10) "More holistic networking of services is needed."

1I) "We need more staff time to make linkages and integrate services." Twenty-nine of the 34 service providers interviewed stated that services to the adolescent mothers were not sufficient in Washington County. Two respondents said that services were sufficient in their service or catchment area. One respondent did not know whether services were sufficient or not.

When asked how services could be made more effective and efficient, agency respondents stressed the need for more concentration on prevention of pregnancy at the formal educational level, since schools appear to have 
the most inclusive contact with young people of this age group. However, one school counselor saw a "growing resistance within the school system to do an adequate job of sex education, prevention, and support services." The main difficulty in the schools was seen in maintaining a balance between "giving sexual information and condoning sexual activity." One agency stated it was "meeting opposition to its counseling program from the local Roman Catholic Church." Abortion counseling was quoted as being "a hot issue." Many providers said they were limited to counseling by confusion as to what is legally allowed and requested some clarification on this issue.

\section{INTERAGENCY LINKAGES}

One intention of the survey was to look at the level of "networking" among the service providers in delivery of services to adolescent mothers. Three questions were asked about referrals. The responses provided good input into the current interagency cooperation.

1) How are clients referred to you?

2) To which agencies do you refer most frequently?

3) With which agencies are services most frequently coordinated?

Eight agencies were named most frequently by the providers. It is probable these agencies have the largest number of contacts with adolescent mothers and provide a nucleus of existing services to this target population. The eight agencies named most often were:

1) Washington County Health Department.

2) Children Services Division

3) Private Physicians.

4) Washington County Adult and Family Services. 
5) Virginia Garcia Health Center.

6) White Shield.

7) Boys and Girls Aid Society

8) WIC Program.

When asked if they were aware of interagency linkages, task forces, training, or skill sharing, six respondents said they were not aware of such opportunities. Eighteen respondents said that they were aware of the Washington County Task Force on Adolescent Pregnancy. Two respondents mentioned a comprehensive program being sponsored by Virginia Garcia Health Center.

AGENCY PHILOSOPHY, FUTURE PLANS AND FUNDING

When asked to briefly described their organizations' primary purpose, only two of the 34 different respondents listed "services to adolescent mothers." There were 14 different categories given as organizations' primary purposes. Educational activities were mentioned 18 times, counseling 16 times, information and referral nine times, and health care eight times. Respondents were asked about their source of funding. Fifty percent said their agencies received some county funds, with two agencies totally county-funded. Thirteen agencies (38\%) received some federal funds, of which four were totally federally funded. Ten service providers were school districts that rely on the local tax base. Five agencies received fees for service. 


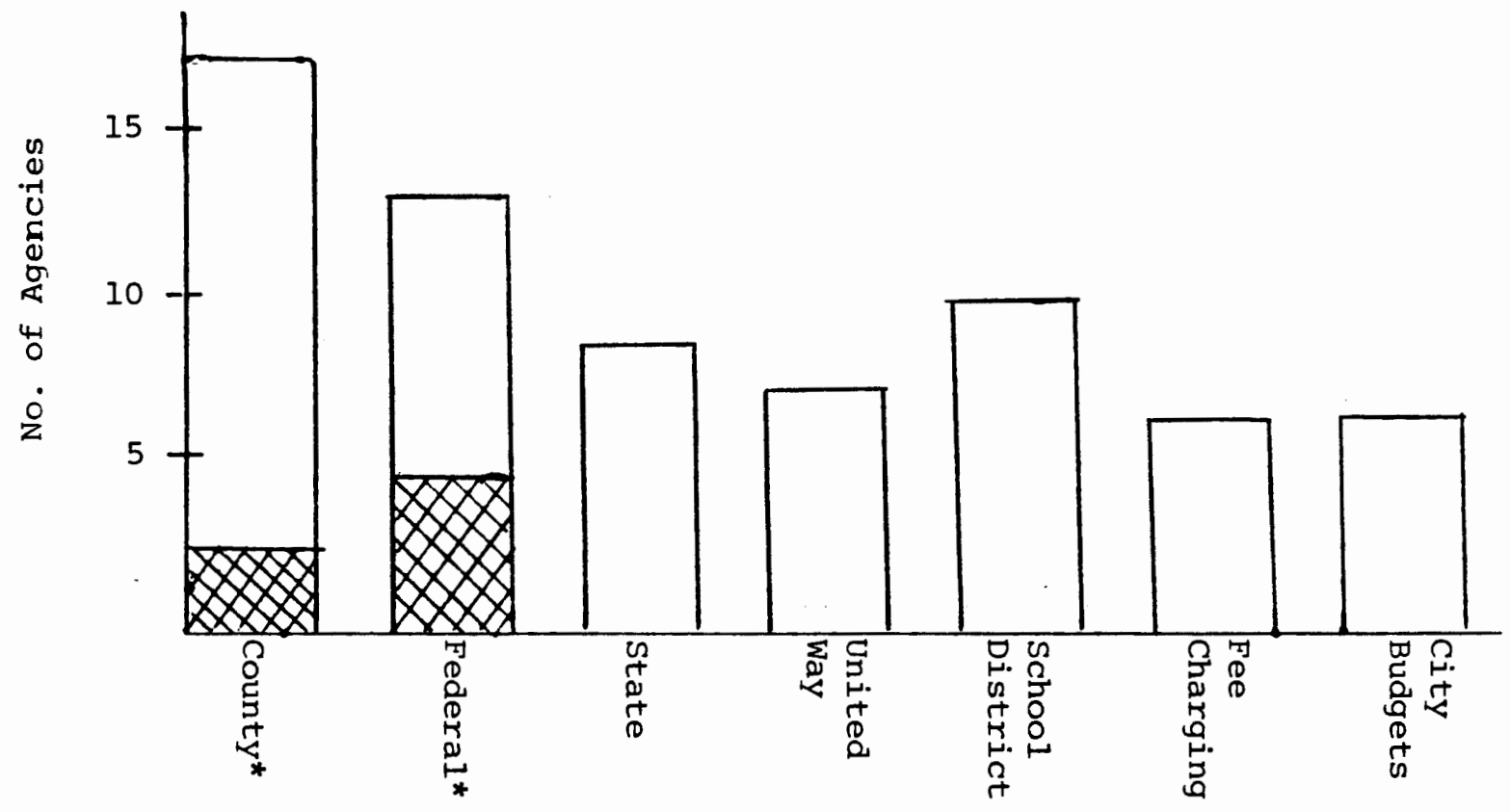

34 agencies - 55 responses

*Crosshatching represents agencies funded entirely through County or Federal funds.

Figure 5. Sources of agency funding.

When asked what proportion of their total agency budget was specified for adolescent mothers, one respondent indicated their agency allocated $33 \%$, two agencies allocated 10\%, and one agency $2 \%$. Nine respondents estimated services to adolescent mothers amounted to less than $1 \%$ of the agency budget. Nineteen respondents said they had no designated budget for this service. 


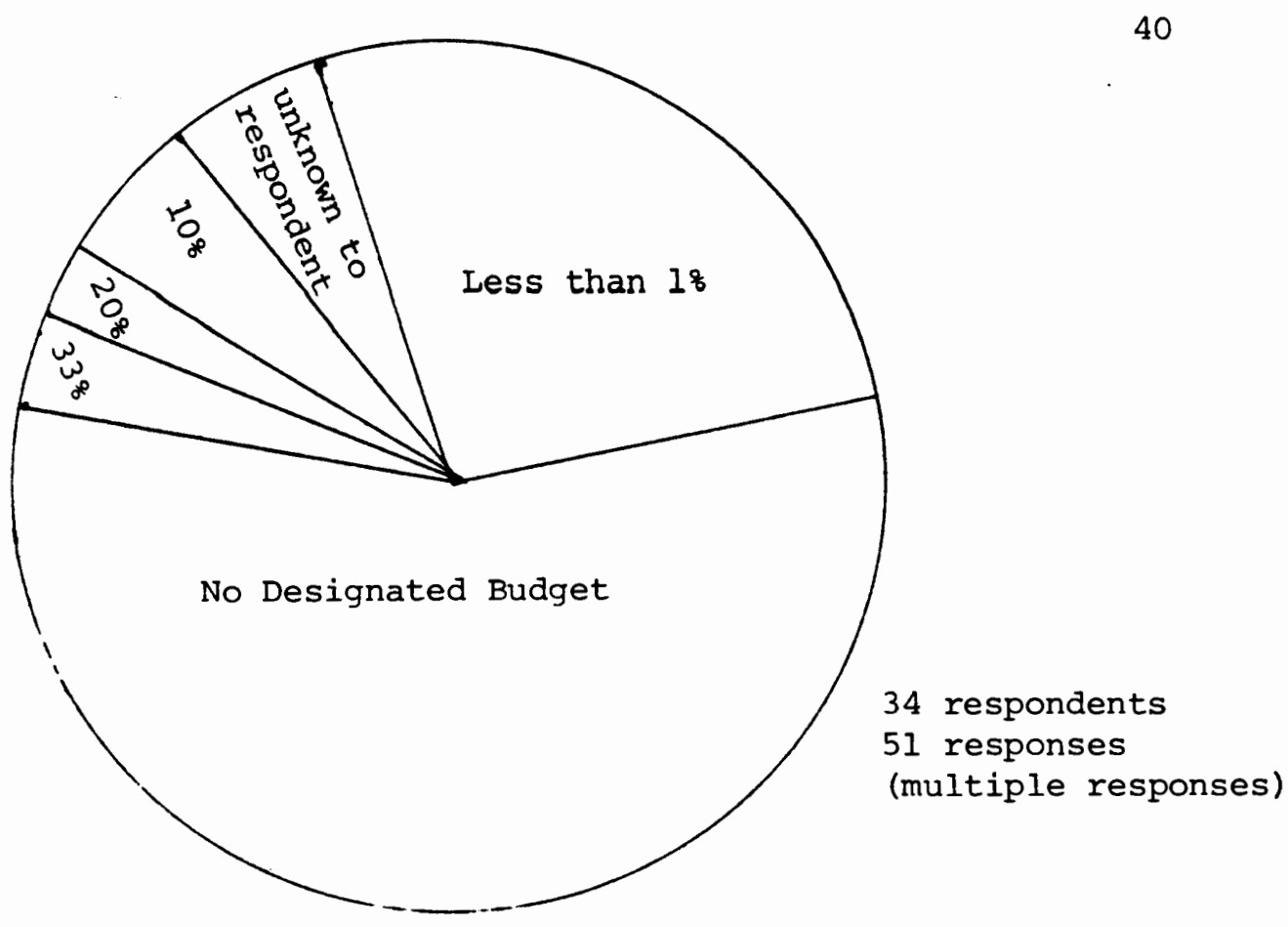

Figure 6. Allocation of agency funds for services to adolescent mothers

The school counselors interviewed gave some insight into the difficulties present in reserving money in school budgets for services to pregnant teenagers. There seems to be no way to estimate how many young women will become pregnant and need services in any given school year. Home study costs through the school system are quoted as being approximately $\$ 2,000$ per home study student. One counselor observed: "When a woman asks for home study we must provide it and shuffle other services around. There is not enough money in the budget to do what we are legally bound to do and every extra service we include we dilute the limited budget further." Another counselor commented upon the tremendous amount of paper work required to classify adolescent mothers for educational services.

When asked if their programs for adolescent mothers had been cut back, expanded, or remained the same in the past six months, ten respondents said 
their programs had been cut back; 12 said their programs had been expanded; and 12 said their programs had remained the same.

Respondents were asked about future plans for providing services to adolescent mothers. Fourteen of 34 responded that there were no plans for change and that services would remain the same. Five reported services to adolescent mothers will be cut due to budgetary decreases. One respondent mentioned that their agency intends to sponsor legislation at the 1981 State Legislative Assembly to improve or increase services to adolescent mothers.

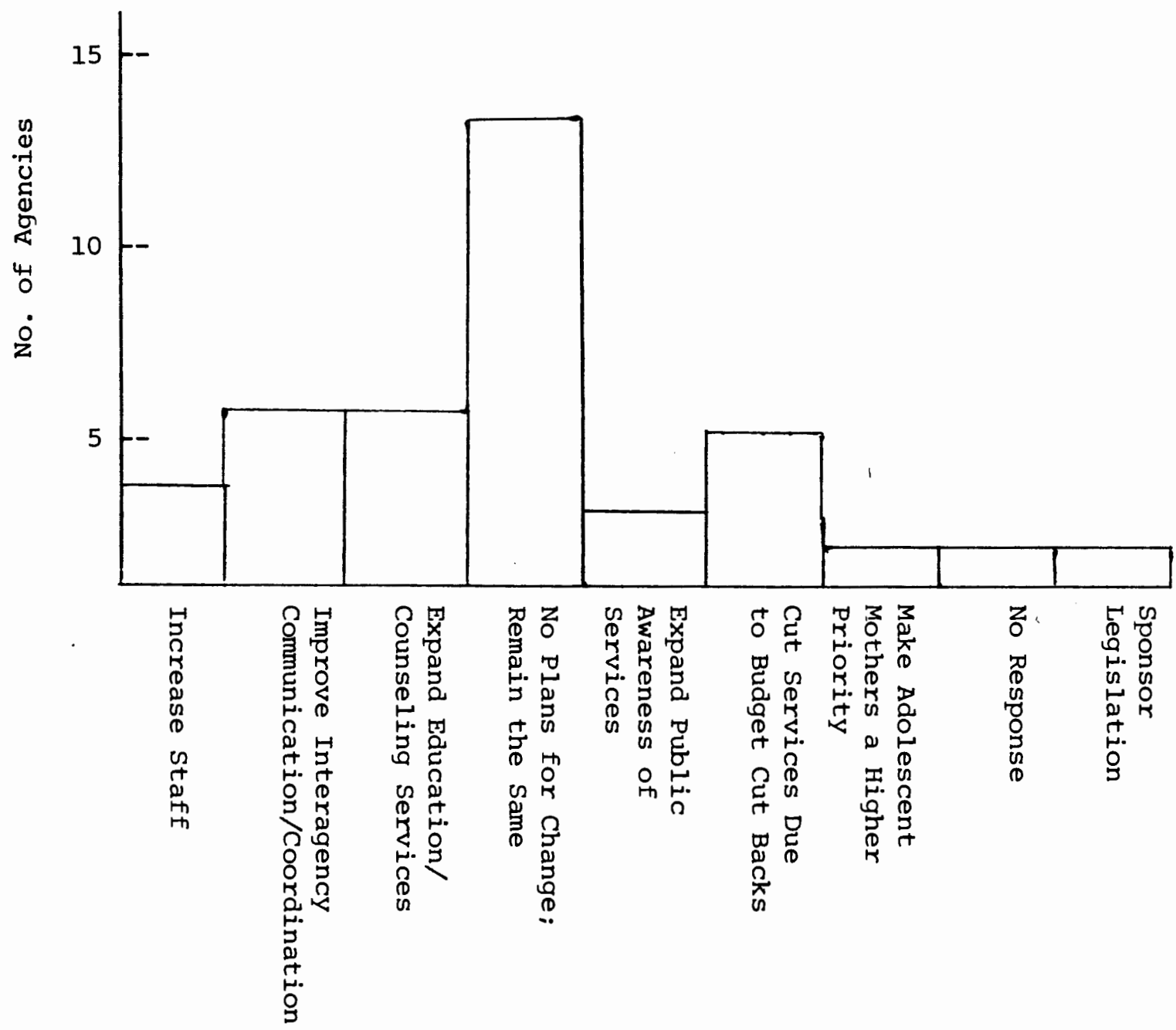

Figure 7. Future plans for services to adolescent mothers. 
Projected budget cuts and current lack of funding were cited by service providers as having serious implications on the already insufficient services to adolescent mothers in Washington County. However, few service providers indicated that their agencies were specifically addressing the following factors: 1) expanding public awareness of the needs of adolescent mothers; 2) advocating for services for adolescent mothers; 3) sponsoring legislation. 
CHAPTER IV

DESCRIPTION OF THE TARGET POPULATION

INTRODUCTION

The purpose of this chapter is to describe the characteristics of adolescent mothers in Washington County.

A questionnaire was designed to be distributed to adolescent mothers to obtain feedback from them regarding those services they were receiving and those they wished to receive. The Teen Mothers Questionnaire is divided into five sections in order to describe different aspects of the young women's lives.

Section I of this chapter contains a description of the questionnaire and the population surveyed.

Section II addresses the limitations of this survey. Section III describes the health care of the respondents. Section IV addresses the educational status of the respondents. Section $V$ describes services the young women received during and after their pregnancies.

DESCRIPTION OF THE QUESTIONNAIRE

The Teen Mothers Questionnaire (Young Mother's Needs Assessment, Appendix D) was designed to be distributed to young women aged 19 and under, who were either pregnant or parenting. The purpose was to collect 
data about the services they found available in washington County and the services they wanted, but did not receive or could not find.

Questionnaires were distributed with the help of three different programs in Washington County. The programs were: 1) Washington County Public Health. Nurses distributed the questionnaires to pregnant or parenting young women in their "high risk" group and those involved in the prenatal clinic. They returned 20 questionnaires. 2) Beaverton High School's "Continuing Education for Young Parents" class directed by Mary Bloom, which returned five questionnaires. 3) The Virginia Garcia Clinic, which returned four questionnaires.

Overall, a total of 29 questionnaires from adolescent mothers or expectant teen mothers were returned. The questionnaires were coded in such a way that the source of distribution could be identified while the respondents remained anonymous.

The questionnaire was distributed from December 15, 1980, until January 31, 1981. The programs distributing the questionnaires gave them to the young women to complete and return on their own. A self-addressed, stamped envelope was provided for this purpose.

A cover letter was attached to each questionnaire which explained who was conducting this survey, why it was being conducted, and what information was needed. It also explained that the questionnaire was confidential and listed two numbers the respondents could call if they had questions. (Refer to Appendix D for a sample of the cover letter and the questionnaire.)

\section{LIMITATIONS OF SURVEY}

The purpose of this survey was to explore the needs of adolescent mothers in Washington County to provide a description of this particular 
population; what their service needs are, and what services are currently being provided for them. The young women who responded to the questionnaire were not randomly drawn from the population. The fact that the mother's age is not recorded on birth information kept by the Health Department made a retrospective random sample impossible.

The respondents were young women having contact with one of the following three programs: Washington County Public Health, Continuing Education for Young Parents, and the Virginia Garcia Clinic. It is difficult to determine if the needs reported in this survey are representative of the entire population, or of those in need of the services specifically available at these agencies. It is also difficult to determine what percentage of adolescent mothers flow through the particular agencies distributing the questionnaire. The majority of the respondents were contacted through Washington County Mental Health, located in Hillsboro. Therefore, the respondents from that area are over-represented.

There was no training given to those distributing the questionnaire. It was therefore impossible to control the consistency in the method of delivery used.

Because of the close proximity to Multnomah County, it is difficult to determine what percentage of this population sought services in the larger, more metropolitan county as opposed to Washington County.

The questionnaire was lengthy in order to extract the details of this population's needs. A large number of open-ended questions were left unanswered. It is possible that the length of the questionnaire became tedious, or perhaps the open-ended questions were confusing to this population. 
DESCRIPTION OF RESPONDENTS

For the purpose of consistency, the respondents were divided into two categories: 1) those less than 15 years of age, and 2) those 15 to 19 years of age. Of the 28 participants who responded to this question, the ages of the young women ranged from 14 years to 20 years, with 16.7 being the average age and 18 years being the mode age. The breakdown of ages was as follows:

TABLE V

AGE OF RESPONDENTS

Age of Respondents

Less than 15 years of age

15 to 19 years of age

20 years of age*

No response

TOTAL

*One respondent was 20 years old. Her responses were included because she had been pregnant while in the 15 to 19 year range. (Also refer to Table XX.)

of the 28 who responded regarding race, 22 described themselves as Caucasian, four as Native American, one as Mexican American, and one described herself as "other," indicating German/Japanese ethnicity.

The cities where the young women lived are shown in descending order in Table VI.

Number of Respondents

1
26
1
1
29


TABLE VI

CITY OF RESIDENCE

City

Hillsboro

Beaverton

Forest Grove

Aloha

Cornelius

TOTAL
Number of Respondents

13

10

4

1

1

29

As indicated by this table, the majority of respondents reported living in Hillsboro. This was expected since a majority of the data was collected from a Hilisboro agency.

Twenty-two respondents listed themselves as single, and seven listed themselves as married. Of those who reported being married, one indicated she was separated from her husband. (See Table XX.)

When asked who they live with, the respondents answered as follows:

TABLE VII

RESPONDENTS' IIVING ARRANGEMENTS

Who They Live With Number of Respondents

Parents

14

Boyfriend

8

Husband

4

Foster Care

1

Other*

3

TOTAL 30 * 
TABLE VII, Continued

*Of those that indicated "other," two respondents reported living with a sister and one reported living with a girlfriend. All 29 respondents answered this question, with one respondent giving two answers by saying she lives with her parents and her boyfriend. None of the respondents indicated living alone.

When asked how they support themselves, the responses were as follows:

TABLE VIII

SOURCE OF FINANCIAI SUPPORT

Supported By:

Parents

Welfare

Boyfriend

Husband

Self/Job

Other*

TOTAL
Number of Respondents

10

$$
7
$$

5

5

2

3

32

*Of the three that answered "Other," they listed their means of support as "benefits," babysitting, and CETA. One respondent gave two different means of support, two respondents gave three different means of support.

As suggested by the table, the majority of the respondents were dependent on their parents for financial support.

Income levels were divided into three categories: low, medium, and high. Low was defined as an income of less than $\$ 5,000$ a year to $\$ 10,000$ a year. Medium was defined as an income of $\$ 10,000$ to $\$ 20,000$ a year. 
High was defined as an income of $\$ 20,000$ a year to $\$ 30,000$ a year. When asked to include themselves within one of these categories, the answers were as follows:

\section{TABLE IX}

INCOME STATUS OF RESPONDENTS

Income Level

Low

Medium

High

No Response

TOTAL
Number of Respondents 20

2

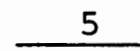

29

(See also Table I.) The two respondents who reported income levels in the medium range included one who described the income as her husband's and one who described the income as her boyfriend's. Both teens who reported incomes in the high range explained that these were parents' incomes. Of the seven listing themselves as married, five reported they were supported by their husbands. The remaining two reported being supported by "benefits" and welfare and indicated that they were living with their parents. This information is shown in the following table: 
TABLE $\mathrm{X}$

\section{AGE, MARITAL STATUS, AND INCOME LEVELS OF ADOLESCENT RESPONDEIJTS}

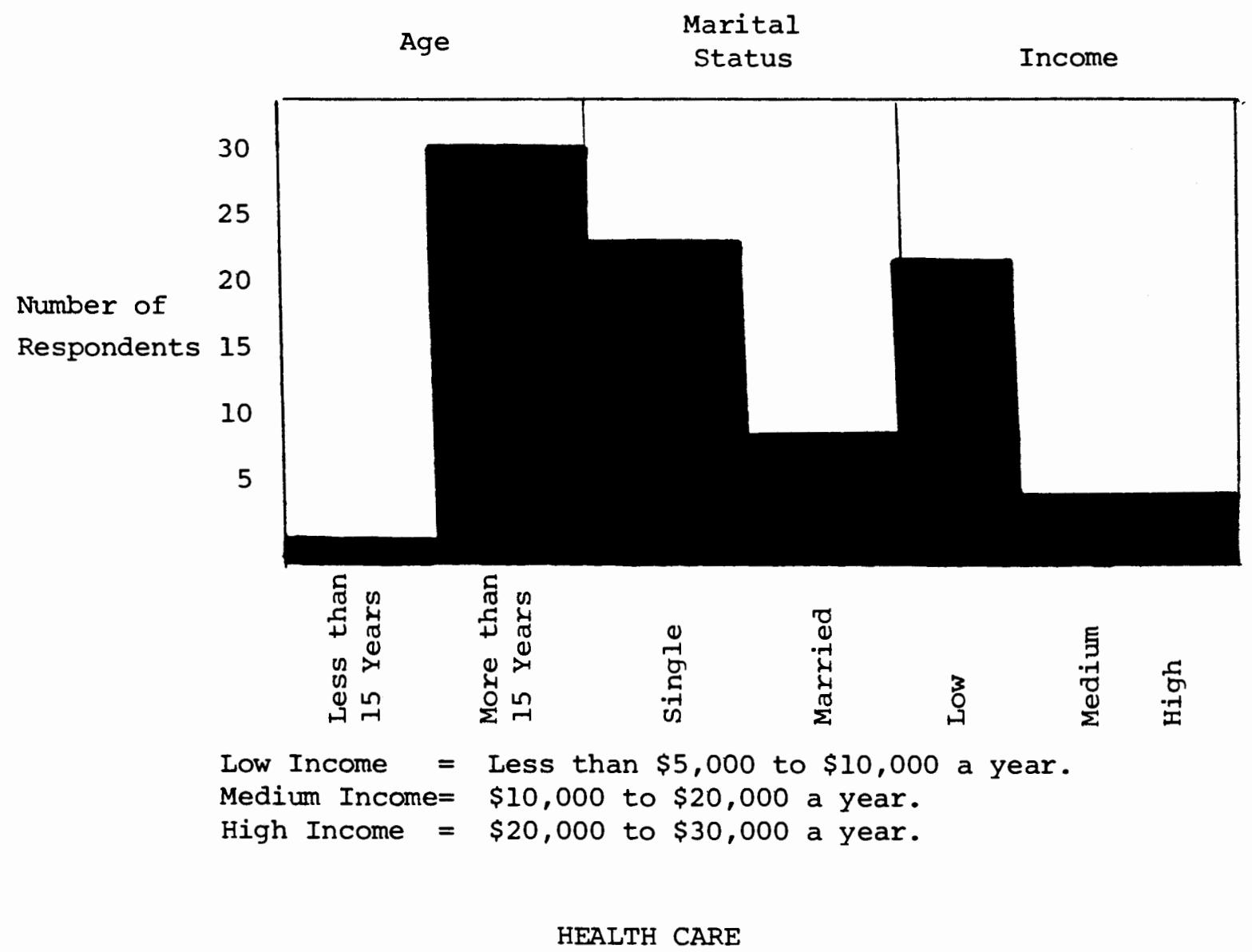

The findings in this section focus upon the prenatal and postnatal care of the young women. This section explores the predicted outcome of the pregnancies for those respondents currently and previously pregnant. Of the 29 young women who completed the questionnaire, 15 reported being pregnant at the time of distribution. Twelve reported they were not pregnant at the present time. One respondent reported being unsure as to whether whe was pregnant, and there was one who did not answer. The following is a breakdown of currently reported pregnancies: 
TABLE XI

RESPONDENTS CURRENTLY PREGNANT

Those Currently Pregnant

\begin{tabular}{lc} 
Yes & 15 \\
Unsure & 1 \\
No & 12 \\
No Answer & 1 \\
TOTAL & 29 \\
\hline
\end{tabular}

TABLE XII

RESPONDENTS WHO PLANNED PREGNANCY

Was This a Planned Pregnancy

Yes

Unsure

No

No Answer

TOTAI
4

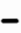

12

13

29

The average month of pregnancy reported by those respondents pregnant at the time of distribution was 5.7 months. The range of months into pregnancy was three to nine months.

All of the young women pregnant at the present time, including the respondent who reported being unsure of pregnancy, indicated they planned to keep their babies. 
of the four respondents who reported this was a planned pregnancy, three reported they were married and one reported being engaged.

Of the 29 respondents, 20 reported they had been pregnant before. However, out of the 20,11 of the respondents were not pregnant at the time of the distribution of the questionnaire. The following is a breakdown of previous pregnancies:

TABLE XIII

RESPONDENTS PREVIOUSLY PREGNANT

Pregnant Before Once Before Twice Before

\begin{tabular}{lccc} 
& & & \\
Yes & 20 & 15 & 3 \\
No & 8 & -- & -1 \\
No Answer & 1 & 14 & 26 \\
TOTAL & 29 & 29 & 29 \\
\hline
\end{tabular}

*Nine of these respondents are also currently pregnant.

Of the 20 respondents who reported being pregnant before, 11 kept the baby, two had an abortion, two gave the baby up for adoption, and three miscarried. (Two of the respondents reported they had miscarried twice.) Two of the respondents did not indicate what the outcome of their pregnancies had been.

Of the nine respondents who have been pregnant more than once, the age and the number of times pregnant was as follows: five of the 18 year olds were on their second pregnancies; and two of the 19 year olds were on their third pregnancies.

In Zelnick's article (1980), 29 the older respondents were more likely to have repeated pregnancies. This was a trend that was found to be consistent with the respondents of this survey. 
Of the 20 young women who reported being pregnant before, three reported that these pregnancies were planned. Sixteen reported that their previous pregnancies were not planned. There was one non-response.

When asked about prenatal care, 22 of the 29 respondents reported that they were receiving or had received prenatal care. Five of the respondents said they had not received prenatal care; two of the respondents did not answer.

When asked at what month of pregnancy they began receiving prenatal care, the responses were as follows:

TABLE XIV

PRENATAL CARE RECEIVED

The Month Prenatal Care was Received Number of Responses

First month 2

Second month 3

Third month 4

Fourth month 2

Fifth month

3

Sixth month

3

Did not receive

7

No answer

TOTAL 29

When asked where the prenatal care was received, the responses were as follows:

TABLE XV

SOURCE OF PRENATAL CARE

Private Doctor

Public Health Nurse

Hospital

*Agency

Did not receive

No Answer 
TABLE XV, continued.

*The two agencies cited as sources used to secure prenatal care were Boy's and Girl's Aide and the Washington State Welfare Department.

$\star \star$ Respondents were allowed to answer more than once. Therefore the frequency did not equal 29.

As indicated by Table XV, the majority of respondents reported receiving prenatal care from a private doctor.

Ten of the respondents reported they had received postnatal care, six reported they had not received medical care after the birth of their babies. Of those young women who did not answer the question, 12 of them were not pregnant at the time.

Four of the respondents reported receiving postnatal care in the first month after the birth of their babies. Two reported care was received in the second month, and one reported receiving medical care 11 months after the birth of her baby. Three of the respondents who reported receiving postnatal care did not indicate when this care was received. Six of the respondents reported receiving postnatal care through a private doctor, three received care in the hospital, and one respondent reported receiving postnatal care through a public health nurse.

\section{EDUCATION}

In addressing the education of the respondents, four areas were emphasized: 1) where they attended school before becoming pregnant, 2) if they continued after becoming pregnant, 3) where they continued, and 4) if they were aware of the school's responsibility to help them continue if they wished to. Below is listed in descending order those schools attended by the respondents before they became pregnant. 
TABLE XVI

SCHOOLS ATTENDED BEFORE PREGNANCIES

School

Number of Respondents

Hillsboro High School

6

Sunset High School

3

Forest Grove High School

2

Neil Armstrong Jr. High

2

Beaverton High School

2

Centennial High School

1

Newberg High School

Glenco High Schocl

J.B. Thomas Junior High

Cedar Park Junior High School

Job Corps (Astoria, Oregon)

Chula Vista High School (in California)

Avondale Jr. High School (in Arizona)

No Responses

Not previously attending any school*

TOTAL

29

*All three of the respondents who reported not attending any school before becoming pregnant listed themselves as single.

When asked what school they attended if they continued their education after becoming pregnant, the responses were as follows:

TABLE XVII

SCHOOL ATTENDED AFTER PREGNANCY

School

Number of Respondents

Hillsboro 3

Forest Grove

2

Banks

1

Sunset

1

C.E. Mason

1

Cedar Park

Continuing Education for Young Parents

Home Tutor

1

"Opportunity School"

No response

TOTAI 
Four of these respondents reported they continued their education after becoming pregnant at the same school they were previously attending. Of the 21 responding to the question, "Have you received your GED or high school diploma?" two reported that they had a GED and three reported they had a high school diploma. Of those who had not already received a GED or high school diploma, two reported they were in the process or expecting to receive a GED. Four reported they were in the process of or expecting to receive their high school diploma. One respondent reported a desire to obtain her GED but she was not in the process of doing so at that time. (see Table XIX.)

of the 13 respondents who gave explanations as to why they did not continue their education after becoming pregnant, the reasons given were:

TABLE XVIII

REASONS FOR NOT CONTINUING EDUCATION Number of Respondents

Quit school before becoming pregnant 3

Lack of money to continue/needing to support themselves

Didn't need to, had obtained GED

Got married

Moved out on her own

Not wanting to be behind her peers

"School itself"

"Schools, not enough time"

No response

TOTAL 29

When asked if they were aware the school must help them continue their education if they desired, 16 said they were not aware of this and ten indicated that they were aware of the school's responsibility. (See Table XIX.) 
When asked where they learned about the school's responsibility in providing continuing education, seven reported their school, school counselor, or teacher informed them, two reported receiving this information from their mothers, and one indicated inquiring with the school board when a friend became pregnant.

The overall responses suggest that the majority of pregnant adolescents are unaware of the Oregon State Statute 343.007 (See Appendix C) that requires the school districts to inform pregnant teens of the opportunity to continue their education and to help provide assistance to them if they wish.

TABLE XIX

EDUCATION ASPECTS

\begin{tabular}{lll} 
Did you continue & Have you received & Did you know school \\
education after & GED or high school & tinue education \\
becoming pregnant? & diploma? & if you wish? \\
\hline
\end{tabular}

\begin{tabular}{lccc} 
Yes & 12 & 5 & 10 \\
No & 15 & 16 & 16 \\
No response & 2 & $\frac{8}{29}$ & $\frac{3}{29}$ \\
TOTAL & $\frac{29}{29}$ & -16 & \\
\hline
\end{tabular}

\section{SERVICES}

The services the respondents wanted to receive during and after pregnancy are listed below. Because the respondents were asked to mark any or all of the services listed, the frequency of responses will exceed the total number of responses. The services are broken into categories by priority: High representing 10-12 responses; Moderate representing six to nine responses; and Low representing one to five responses. 
TABLE XX

SERVICES WANTED DURING AND AFTER PREGNANCY

Wanted During Pregnancy

\begin{tabular}{ll}
\multicolumn{1}{c}{ High } & 12 \\
Housing & 11 \\
Job Training & 10 \\
Financial Aid & 11 \\
Transportation &
\end{tabular}

Moderate

Legal Information

Career Counseling

Nutritional Guidance

Young Mother's Group

Parenting Information

Alternative School

Birth Control Information

Clothing

12

11

10

11

Wanted After Pregnancy $F$

$\begin{array}{ll}\frac{\text { High }}{\text { Financial Aid }} & 11 \\ \text { Housing } & 10\end{array}$

11

Moderate

Parenting Information 9

Child Care 9

Job Training 8

Nutritional Guidance 7

Legal Information 6

Alternative School 6

Career Counseling 6

Birth Control Information 6

Clothing

6

Low

Low

Child Care

Transportation 5

Abortion Counseling 3

Adoption Counseling 3

Young Mother's Group

Abortion Counseling

Adoption Counseling

Housing and financial aid are services that are a high priority both during and after pregnancy. Job training was a high priority service during pregnancy and slipped to a moderate priority after pregnancy. Chaskel (1967) ${ }^{30}$ noted the need for housing for pregnant unmarried girls who cannot remain with family as a high priority. He also points out that job training and financial aid are much needed services.

Young mother's groups were a moderate priority service during pregnancy and a low priority service after pregnancy. Adoption and abortion counseling were low priority services both during and after pregnancy. This finding 
is understandable since the majority of young women both currently and previously pregnant opted to keep their babies.

Child care was the only service having a higher priority rating

after pregnancy. There was more reported need for service during pregnancy than after.

The services that respondents had received during and after their pregnancy are reported in the table below. Again, these services are broken into categories by priority: High representing ten to 12 responses; Moderate representing six to nine responses; and Low representing one to five responses. The respondents were asked to mark any or all that apply, so again, the frequency will exceed the total number of responses.

TABLE XXI

SERVICES RECEIVED DURING AND AFTER PREGNANCY

Received During Pregnancy F

$\underline{\text { High }}$

Nutritional Guidance Birth Control Information

Moderate

Financial Aid

Parenting Information

Abortion Counseling

Low

Clothing

Young Mothers Group

Legal Information

Adoption Counseling

Child Care

Housing

Transportation

Alternative School

Job Training

Career Counseling
Received After Pregnancy F

High

12

10

Moderate

Nutritional Guidance 7

Birth Control Information 7

Financial Aid

6

Low

Abortion Counseling 4

Parenting Information 3

Legal Information 3

Adoption Counseling 2

Clothing 2

Housing 2

Transportation 2

Job Training 1

Alternative School 1

Career Counseling 1

Young Mothers Group 1

Child Care 1 
Nutritional guidance was a service frequently received during pregnancy. It was also a service moderately received and wanted after pregnancy. Birth control information was another service that follows this trend. Respondents reported receiving or wanting to receive more services during their pregnancies than they reported receiving or wanting to receive after their pregnancies. It could be that it is difficult for them to foresee what their needs may be after the pregnancy. Comparisons between the services the girls wanted and those they received are difficult to determine as the respondents may have responded to wanting a service and also receiving that service.

When asked which agencies or individuals helped the respondents in finding needed services, their answers were as follows:

TABLE XXII

SERVICE SOURCES

Which Individuals or Agencies Helped Number of Responses

\begin{tabular}{lc} 
**W.I.C. & 8 \\
**Welfare & 7 \\
Washington County Health Department & 4 \\
Families & 3 \\
Friends & 2 \\
Teachers & 2 \\
Childrens Service Division (C.S.D.) & 1 \\
University & 1 \\
School Counselor & 1 \\
Nobody & 1 \\
"Nobody, I did the best I could" & 1 \\
*TOTALS & 31 \\
\hline & \\
*Respondents were allowed to answer more than once. \\
**W.I.C. and Welfare were cited in combination by four respondents.
\end{tabular}

When asked if they felt comfortable in contacting the agencies or individuals, 16 of the respondents reported that they did feel comfortable 
and four reported they did not feel comfortable in contacting those persons or places they sought for assistance. There were no reasons given as to why the four respondents were uncomfortable in contacting the sources they did. When asked how they found out about the services they used, the respondents were instructed to list all the referral sources that helped them. The breakdown of these sources is as follows:

TABLE XXIII

INFORMATION SOURCES

Found Out About Services Through Number of Respondents

Friends
Parents
School Counselor
Health Nurse
Welfare
Police Department
No Answer

*TOTAL

*Respondents were allowed to answer more than once.

When asked where they would prefer to go to get the services they need, two of the respondents cited welfare, one said parents and friends, a caseworker was cited by one respondent, and a school counselor was cited by another. One respondent said (sic) "No where because I feel a shame to have to take cherite" and "Anywhere cause I do need help. But the people need to be friendly and care."

Four of the young women reported they had been denied service. One of the respondents did not know why she had been denied service and she did not site from whom or where service was denied. One respondent who was denied service said that she had been denied welfare because "No services to couples except food stamps." The third respondent who was denied service 
said "I was refused legal services, I was unable to afford to pay them." The fourth said "I was denied services from welfare because I had no children right now."

Only one respondent reported that follow-up services had been received. The agency which conducted this follow-up was cited as the Washington County Health Department. However, the majority of the respondents came from the Washington County Health Department's "High Risk" program which is a follow-up service. Therefore, this suggests that the young women misinterpreted the question.

In summary, the data collected reflects that this population is caught in a difficult position between childhood and adulthood. The adolescent mother has not been given the status of a role that is overlapping and mutually exclusive. Teen mothers are faced with the task of incorporating the roles of adult and parent with little emotional or social preparation. 
FOOTNOTES

1. Warheit, G. J., Bell, R. A., and Schwab, J. J. Needs Assessment Approaches: Concepts and Methods. U.S.D.H.E.W., Public Health Service; Alcohol, Drug Abuse, and Mental Health Administration, N.I.M.H., Maryland, 1977.

2. 1980 U.S. Census. Preliminary Figures.

3. Unpublished Report. Center for Population Research and Census. Portland State University.

4. Population Estimates: Oregon Counties and Incorporated Cities. July 1, 1977. The Center for Population Research and Census. Portland State University.

5. 1980 Social Accounting for Oregon, Socio-Economic Indicators, State Community Services Program. Department of Human Resources. Salem, Oregon, 1980. Page 392.

6. Ibid., p. 392.

7. Ibid., p. 393.

8. Ibid., p. 388 .

9. Ibid, , p. 389 .

10. Ibid., p. 43 .

11. 1970 U.S. Census.

12. Center for Population Research and Census. Portland State University.

13. The Census Bureau does not explain what the term "both parents" means. It is not clear whether this includes only "natural parents."

14. Summary of Pupil Personnel for Washington County. Oregon Department of Education, School Management Services Division. School Finance and and Data Information Services. 1980.

15. Ibid.

16. Early School Leavers Study: 1980. Oregon Department of Education, Salem, Oregon, 1980.

17. Ibid., p. 10 . 
18. Op. Cit., Socio-Economic Indicators, 1980, p. 389.

19. Oregon Public Health Statistics Report for Calendar Year 1979. Department of Human Resources, Oregon State Health Division. Vital Statistics Sections. Portland, 1980. Page 9.

20. Ibid., p. 19 .

21. Ibid., p. 20 .

22. Ibid, p. 32 .

23. Induced Abortions in Oregon, Summary: December 1979. Oregon State Health Statistics, Portland, Oregon, 1980, p. 2.

24. Ibid., p. 7 .

25. Ibid., p. 11 .

26. Ibid., p. 6 .

27. Oregon Public Health Statistics Report for Calendar Year 1979, p. 21.

28. Ibid., p. 21 .

29. Zelnick, Melvin; Kim Young and John Kanter, 1979. "Probabilities of Intercourse and Conception Among U.S. Teenage Women," Family Planning Perspectives, XI, p. 172 .

30. Chaskel, Ruth, 1967. "The Unmarried Mother: Is She Different?" Child Welfare, XLVI, p. 74. 
APPENDIX A

ANNOTATED BIBLIOGRAPHY

Ashdown-Sharp, Patricia 1975. Single Woman's Guide to Pregnancy and Parenthood, London: Penguin Books.

The author discusses options and gives information, some of which is specific to the British National Health system.

Bernstein, Blanche and Mignon Sauber 1960. Deterrents to Early Prenatal Care and Social Services Among Women Pregnant Out-of-Wedlock, AIbany, New York: New York State Department of Social Welfare.

This study was intended to determine the extent to which unmarried mothers seek and obtain social and health services during pregnancy.

Bennett, Virginia C. and Jack I. Bardan 1977. "The Effects of a School Program on Teenage Mothers and Their Children," American Journal of Orthopsychiatry, XIVII.

Bernstein, Rose 1971. Helping Unmarried Mothers, New York: Association Press.

The author discusses the social and potential psychological hazards of having a child out of wedlock. She also discusses how to determine services for these clients.

Cermidy, P. and Jacob ziner 1966. "A Study of Young Unmarried Mothers who Keep Their Babies," American Journal of Public Health, LVI, 1252-1251.

This 1960 study on two districts in New York City was carried out in Child Health Stations. The authors concluded that more intensive casework may be needed, but is often delayed or omitted because of resource shortages.

Chaskel, Ruth 1967. "The Unmarried Mother: Is She Different?" Child Welfare, X.VI, 65-75.

Chaskel states that the culture rests on the strength and stability of the family. Therefore, chastisement has been incorporated into a framework of helping. She differentiates between: the poor, those who are psychologically helpless without support, and the emotionally upset. Money can cancel or conceal a pregnancy. Those who are interested in adoption, and whose children will be eligible, have a priority claim on available resources. 
Chaskel, R. 1968. "Changing Patterns of Service for Unmarried Parents," Social Casework, XIIX, 3-10.

Chaskel found that the fewest social hurdles faced those who don't need community support and those who give the child up for adoption. Virtually no financial support (with the exception of A.F.D.C.) is provided on a long-term basis.

Chenoweth, A. D. 1971. "The School-age Pregnant Girl," Journal of School Health, LXI, 347-348.

The author said that the actual number of school-age pregnancies is unknown, but that over 200,000 school-age girls have babies each year. These girls have the problems of incompletion of their own maturity, and are high obstetrical risks.

Because the school system has traditionally excluded pregnant girls, pregnancy has become a major cause of dropping out for girls in the U.S. However, communities which have mobilized educational, medical and social services have shown that as a result: 1) fewer girls have repeated pregnancies; 2) more girls continue their education, and 3) take jobs. There is a need for more coordinating and comprehensive programs. In 1971, approximately 175 programs in over 150 communities served 40,000 school age girls.

Child Welfare League of America 1960. Standards for Services to Unmarried Parents, New York: Child Welfare League of America.

This handbook is directed at service providers. Standards are enumerated, and seen as goals to improve services.

Clark, Ann L. 1967. "The Crisis of Adolescent Unwed Motherhood," American Journal of Nursing, LXVII, 1464-1469.

"The adolescent mother can best be served by a coordinated effort." The author describes several needs, including dealing with guilt, tensions, and reality. The worker must help to decrease feelings of abandonment, and help to nurture feelings of understanding.

Committee on Maternal and Child Care 1967. "American Medical Association Guide for Collaboration of Physician, Social Worker and Lawyer in Helping the Unmarried Mother and Her Child," Journal of the American Medical Association, CXCIX, 858-859.

This article mostly concerns a coordinated effort for services for adoption. They physician is responsible for physical and mental health, the social worker for social and emotional needs, and the lawyer for counseling concerning legal consequences. When the three are acting alone they don't have the resources available to protect and give service for the "best interest of the child and mother." 
Coombs, L. C. et.al. 1976. "Premarital Pregnancy and Status Before and After Marriage," American Journal of Sociology, LXXV, 800-820.

This study had five major findings. 1) The average premaritally pregnant couple had an income of $\$ 1,500$ (1961). 2) The disadvantaged economic position did not result from low status familial backgrounds. The highest percentage of these couples came from middle class families. 3) These couples were shown to get more help from relatives. 4) Husbands in premaritally pregnant marriages have less education and earlier age at marriage. They are three times more likely to finish college without a premaritally pregnant wife. There is not a significant correlation to familial background. 5) One-third of the husbands over the age of 22 years in these marriages had little education. The authors infer that lack of education is conducive to premarital pregnancy.

Ford, K., M. Zelnick and I. F. Kantner. "Parents' Social Status Found to Play Key Role in Daughters' Sexual Activity, Contraceptive Use," Family Planning Perspectives.

The authors found that teenage women whose parents had not finished high school were more likely to have premarital intercourse, and less likely to use contraceptives the first time.

Furstenberg, Frank F, 1976. Unplanned Parenthood: The Social Conseguences of Teenage Childbearing, New York: MacMillian Publishing Co., Inc.

This longitudinal study followed teenage mothers and their children.

Klerman and Jekel 1973. School Age Mothers, Hamden, Conn.: Iinnet Books.

School Age Mothers is a major study. It contrasts two centers offering comprehensive services. One included both educational and medical programs.

Kriesberg, Louis 1970. Mothers in Poverty: A Study of Fatherless Families, Chicago: Aldine Publishing Co.

Kriesberg discusses fatherless families in terms of "the intergenerational transmission of poverty."

Mental Health Division 1965. Proceedings of the Conference on the Unwed Mother: Needs, Psycho-social Dynamics, and Effective Intervention, Salem, Oregon: State of Oregon, Mental Health Division.

Morisey, Patricia Garland 1970. Professional Advocacy, Community Participation and Social Planning: The Case of the Unmarried Mother from the "Inside the Ghetto" Perspective, New York: Columbia University, D.S.W., Social Work.

This doctoral dissertation deals with unmarried pregnancy in the specific context of impoverished, black, single parent families. 
National Conference on Social Welfare 1963. Brief and Intensive Casework with Unmarried Mothers, New York: Child Welfare League of America, Inc.

These two professional papers discuss aspects of casework, including prevention.

National Council on Illegitimacy 1968. Effective Services for Unmarried Parents and Their Children: Innovative Community Approaches, New York: National Council on Illegitimacy.

The authors review services in several U.S. commities and abroad.

National Council on Illegitimacy 1967. Unmarried Parenthood: Clues to Agency and Community Action, New York: National Council on Illegitimacy.

This collection of professional papers is directed at service providers and administrators.

National Institute of Mental Health 1980. "Teenage Pregnancy - Florida Offers Help," Innovations Now, Fall, 34.

The program divides services into three components: general outreach and information; direct service with teens who are pregnant or who suspect pregnancy; and follow-up for one year to determine effectiveness of service.

There are three goals. They are: to prevent school-age pregnancies; then to assist a school girl to continue her education even though unexpectedly pregnant, and then to help her prevent a second unplanned pregnancy.

Nicholson, Jill 1968. Mother and Baby Homes, London: George Allen \& Unwin, Ltd.

Nicholson surveyed homes and care in Great Britain.

Oettinger, Katherine B. 1979. Not My Daughter: Facing Up to Adolescent Pregnancy, Englewood Cliffs, N.J.: Prentice-Hall, Inc.

This book is directed at parents of adolescent girls. It discusses sexuality and communication as well as options in pregnancy.

Ogg, Elizabeth 1976. Unmarried Teenagers: Their Children, New York: Public Affairs Pamphlets.

Teenagers and parents are addressed in this pamphlet, which discusses options for teenage parents.

Osofsky, Howard 1968. The Pregnant Teenager: A Medical, Educational, and Social Analysis, Springfield, Ill., Charles C. Thomas, Publisher. 
Palmer, Mary w. Beginning Community-Wide Services on a Non-Residential Basis for Pregnant School-Age Girls. Chicago: Florence Crittenton Association of America.

Palmer gives information on how to set up services.

Pochin, Jean 1969. Without a Wedding Ring: Casework with Unmarried Parents, London: Constable and Co., Ltd.

The author gives information and case studies for social service providers. She includes options and planning.

Rains, P.M. 1971. Becoming an Unwed Mother, Chicago: Aldine-Atherton, Inc.

The Author has "not made the assumption that critical psychological or motivational differences distinguish unwed mothers from other girls." She has looked "for the concerns which link the early stages of normal sexual careers with the stages which produce unwed mothers."

Terkelsen, Helen E. 1964. Counseling the Unwed Mother, Philadelphia: Fortress Press (Prentice-Hall, Inc.).

This book is directed at ministers seeing church members for counseling.

Thompson, Jean 1967. The House of Tomorrow, Evanston, Ill.: Harper \& Row.

The House of Tomorrow is an adolescent's diary of her stay in a home for unwed mothers.

White, Charles 1981. Report for Community Block Grant, Hillsboro, Oregon: Police Advisory Board.

This is a comparative study on the quality of living, by area, in Washington County. It was conducted through a sample questionnaire survey. Some factors were: family income, housing, recreational activities, transportation, and percentage of minority groups in the population.

Zelnik, Melvin 1980. "Second Pregnancies to Premaritally Pregnant Teenagers, 1976 and 1971," Family Planning Perspectives, XII, 69-76.

Zelnik finds an overall sharp decline in second pregnancies among those with premarital first pregnancies.

Zelnik, Melvin 1979. "Sex Education and Knowledge of Pregnancy Risk Among U.S. Teenage Women," Family Planning Perspectives, XI, 355-357.

The author found that higher socio-economic class (years of education) was correlated with the probability of having had sex education classes. 
Zelnik, Melvin; Kim Young and John Kantner 1979. "Probabilities of Intercourse and Conception Among U.S. Teenage Women," Family Planning Perspectives, XI, 177-183.

The authors found that by age 16, one-fifth of U.S. women have had sexual intercourse; by age 19, two-thirds of U.S. women have had intercourse. One-quarter of those sexually active had premarital conceptions by age 17 , and one-third of the sexually active women had premarital conceptions by age 19 . 
APPENDIX B

ADDITIONAL TABIES

TABLE A

IIVE BIRTHS

Washington County

State

1979

1978

1977

1976

1975

1970

1960

3882

3405

3250

2932

2833

2877

2100

41,564

38,964

37,467

34,840

33,352

35,353

38,347

Source: Oregon Public Health Statistics Reports for Calendar Years 1960-1979.

TABLE B

TEENAGE BIRTHS (UNDER 15 YEARS OF AGE)

Washington County

State

1979

1978

1977

1976

1975

1970

1960

\section{5}

1

4

1

6

4

1

70

72

69

67

67

41

31

Source: Oregon Public Health Statistics Reports for Calendar Years 1960-1979. 
TABLE C

TEENAGE BIRTHS (15-16 YEARS OF AGE)

Washington County

State

1979

335

353

5544

1978

1977

1976

1975

1970

318

5588

321

5303

298

5367

307

5266

1960

201

6027

5896

Source: Oregon Public Health Statistics Reports for Calendar Years 1960-1979.

TABLE D

ABORTIONS (TOTAL)

1979

1978

1977

1976

1975

1970

1960

\begin{tabular}{rr} 
Washington County & State \\
\hline 986 & 14,501 \\
937 & 13,605 \\
820 & 13,163 \\
825 & 12,590 \\
617 & 10,641 \\
428 & 7,187 \\
$--N o t$ Legai-no
\end{tabular}

Source: Oregon Public Health Statistics Reports for Calendar Years 1970-1979.

TABLE E

ABORTIONS (UNDER 15 YEARS OF AGE)

Washington County

State

1979

1978

1977

1976

1975

1970

1960

$\begin{array}{rr}7 & 142 \\ 5 & 106 \\ 11 & 145 \\ 7 & 165 \\ 9 & 155 \\ 5 & 100\end{array}$

Not Legal-- -

142

106

145

165

100

Source: Oregon Public Health Statistics Reports for Calendar Years 1970-1979. 
TABLE F

ABORTIONS (15-19 YEARS OF AGE)

Washington County

State

$\begin{array}{llr}1979 & 362 & 4,697 \\ 1978 & 353 & 4,443 \\ 1977 & 306 & 4,502 \\ 1976 & 313 & 4,491 \\ 1975 & 239 & 3,915 \\ 1970 & 138 & 2,396 \\ 1960 & \text { Not Legal- }\end{array}$

Source: Oregon Public Health Statistics Reports for Calendar Years 1970-1979.

TABLE G

IMMATURE BIRTHS (2500 GRAMS OR LESS)

Washington County

State

1979

1978

170

2,129

153

1,982

128

1,939

136

1,883

168

1,889

149

2,104

105

2,437

Source: Oregon Public Health Statistics Reports for Calendar Years 1960-1979.

TABLE H

UNWED BIRTHS (UNDER 15 YEARS OF AGE)

Washington County

State

1979

1978

1977

1976

1975

1970

5
1
4
1
3
4

62

66

64

61

55

4

38

Source: Oregon Public Health Statistics Reports for Calendar Years 1960-1979. 
TABLE I

UNWED BIRTHS (15-19 YEARS OF AGE)

Washington County

State

1979

1978

114

131

2,188

1977

108

2,250

1976

101

2,003

1,813

1975

92

1,576

1970

65

1,549

Source: Oregon Public Health Statistics Reports for Calendar Years 1960-1979. 
AGENCIES INCLUDED IN SURVEY 1. Family Planning (Dept. of Public Health) 2. Wash. Co. Adult \& Family Services 3. Mult-Wash Co. CETA Consortium (Young Prog) 4. Wash. Co. Ed. Service District (ESD) 5. The Child's Place

6. St. Vincent's Hosp. \& Medical Center 7. Tualatin Valley Mental Health Center 8. Virginia Garcia Health Center 9. WIC Program - Dept. of Public Health 10. Dept. of Public Health

11. Forest Grove Youth Service Center 12. Metro Crisis Intervention Services 13. Tigard Youth Service Center 14. Metropolitan Family Services 15. Prepared Childbirth Assoc. 16. Head Start

17. Wash Co Juvenile Dept. 18. Children Services Division (CSD) 19. Oregon State U. Extension Service 20. Tri-County Community Council 21. Wash. Co. Mental Health System 22. Welfare Hotline/Wash CO. CAP 23. Boys and Girls Aid Society 24. Cont. Ed. for Young Parents 25. Portland Cormity College 26. Sherwood High School 27. Banks High School 28. Forest Grove High School 29. Gaston High Schoo 30. Tigard High School 32. 32. Beaverton High scho 34. Hillsboro High School
ADDRESS $150 \mathrm{~N}$. First, Hillsboro 1657 SE Enterprise Ave., Hillsboro 111 SE Washington, Hillsboro 14150 NW Science Park Dr., Portland 951 SE 13th, Hillsboro 9205 SW Barnes Rd., Portland 14600 NW Cornell Rd., Portland $85 \mathrm{~N}$. 12th St., Cornelius $150 \mathrm{~N}$. 1st, Hillsboro $150 \mathrm{~N}$. lst, Hillsboro

1925 Pacific Ave., Forest Grove $687 \mathrm{~N}$. Thompson St., Portland 13090 SW Pacific Hiway, Tigard 2281 NW Everett, Portland

6446 SW Capitol Hwy, Portland

245 2nd St., Hillsboro

232-W NE Lincoln, Hillsboro

1665 Enterprise Circle, Hillsboro

2448 Tualatin Valley Hwy, Hillsboro

718 w. Burnside, Portland

1679 SE Enterprise Circle, Hillsboro

236 E. Main, Hillsboro

2301 NW Glisan, Portland C.E. Mason School, Center St.

Rock Creek Campus, Rock Creek

1155 Meinecke Rd., Sherwoo

Banks High School, Banks Forest Grove High School,

400 Durham Rd., Tigard

575 NW Murray Rd., Beaverton

13000 SW 2nd, Beaverton

SW 185th \& Kinnainan Rd

SW 185th \& Kinnainan Rd., Aloha

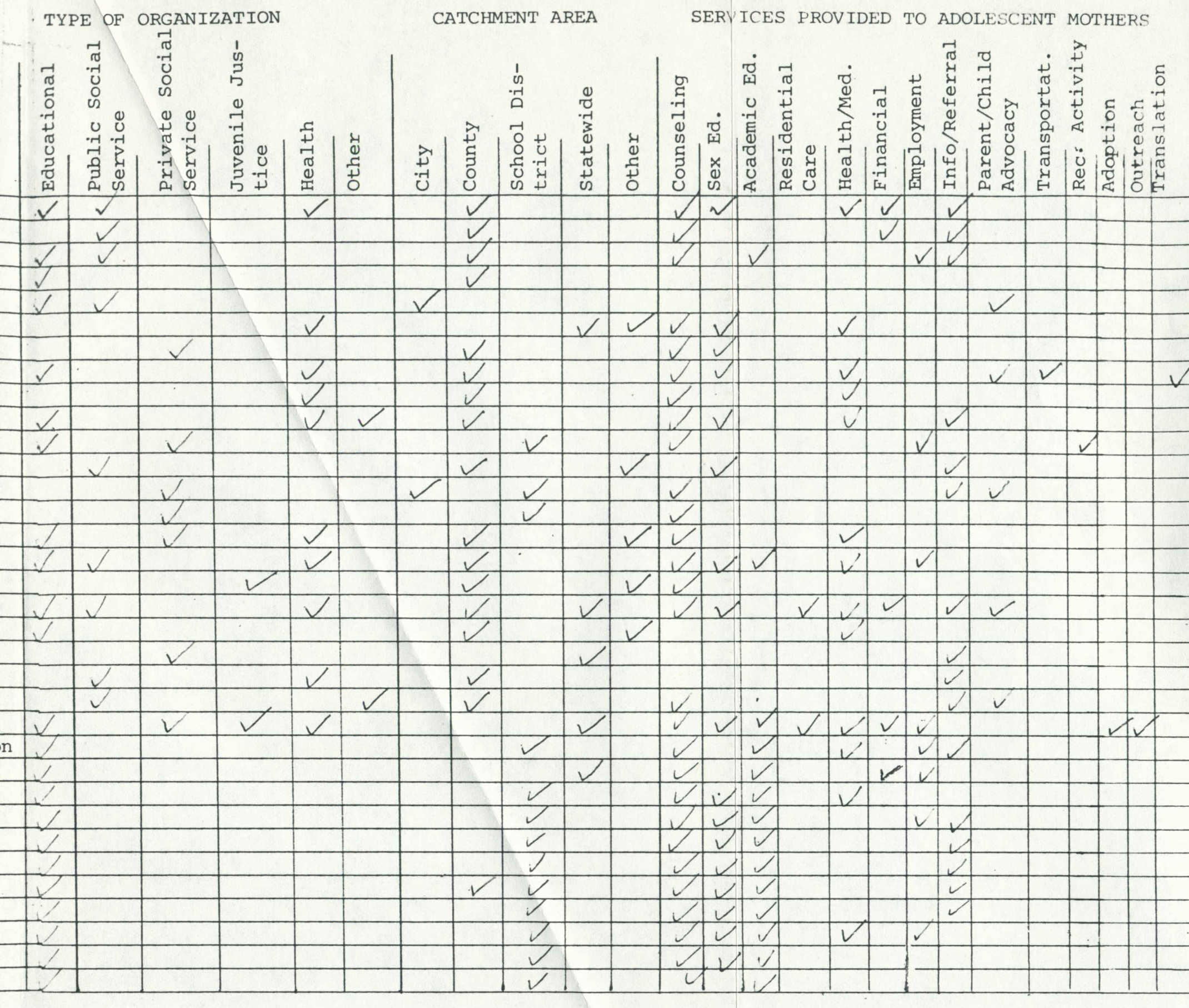




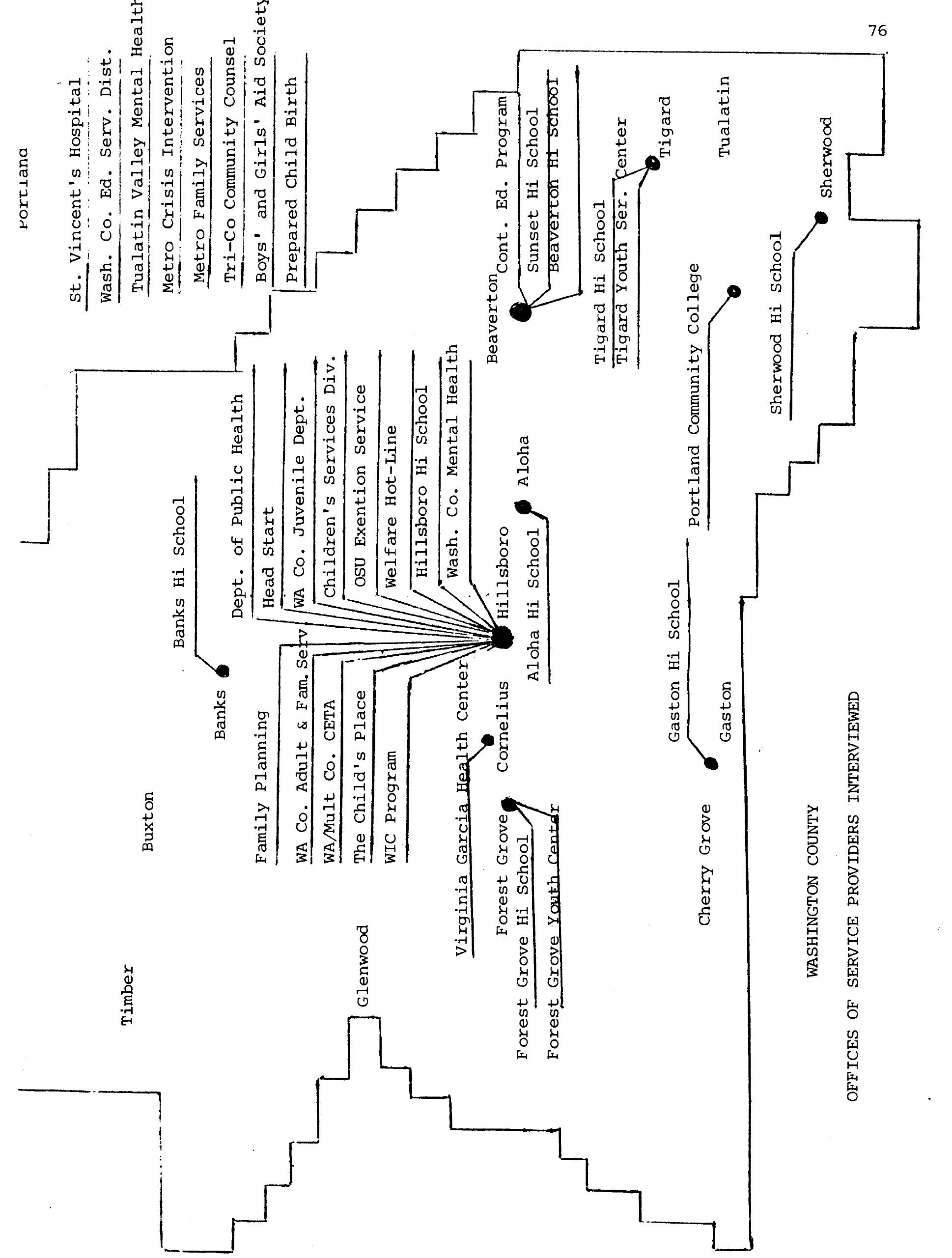


(11) A certificate of need shall not be bought, sold nor transferred either on its own or as part of a facility or healtin service purchase, sale or transfer.

Approved by the Governor May 25, 1979.

Filed in the Office of the Secretary of State May 25, 1979.

\section{CHAPTER 175}

$$
\text { AN ACT }
$$

[SB 113 ]

Relating to education; amending ORS 343.077.

Be It Enacted by the People of the State of Oregon:

Section 1. ORS 343.077 is amended to read:

343.077. (1) A child shall be considered for special education upon application by the parent, legal guardian or surrogate of the child or by the school district. Upon appropriate evaluation the child may be found eligible for special education under a school district program approved under ORS 343.221. Such evaluation shall be made within a reasonable time.

(2) A child who is thought to be eligible and in need of special education by the school authorities or parents, guardians or surrogate of the child shall neither be placed in, transferred from nor be denied placement in such a program unless the administrative officers of the school district shall have properly notified the parents, legal guardians or surrogate of the child of such proposed placement, transfer or denial and the right to due process. The proceedings shall be those for a contested case under ORS [ chapter 1831183.310 to 183.500 with the school district being the agency within the meaning of applicable provisions of ORS [chapter 183] 183.310 to 183.500 . The notification must be in the parents', guardian's or surrogate's native language, unless it is clearly not feasible.

(3) The parents, guardians or surrogate of the child shall be given an opportunity to examine all relevant records with respect to the identification, evaluation, and educational placement of the child and to obtain an independent educational evaluation of the child if the parents, guardian or surrogate disagrees with the evaluation obtained by the sch(o)l district. If there is disagreement, before the second evaluation is commenced, the school district may initiate a hearing as a contested case under ORS [chapter 183] 183.310 to 183.500 to show that its evaluation is appropriate. If the final decision is that its evaluation is appropriate, the parents, guardian or surrogate still has the right to an independent educatior:ai evaluation but not at the school district's expense. If, however, the district's evaluation is found inappropriate, the independent evaluation shall be conducted at the district's expense.

(4) The Department of Education shall establish by rule procedures to protect the rights of the child whenever the parents or guardians of the child are unknown or unavailable, or the child is a ward of the state. Whenever the parents of the child are unknown or unavailable or the child is a ward of the state, an individual, who is not an employe of the department or the educational unit involved in the education or care of the child, shall be appointed to act as a surro- gate for the parents or guardian of the child I hi. Department of Education shall appoint the surregats: from a list of nominees submitted by the State $A d v i$. sory Councii for Handicapped Children, the Or.gon Developmental Disabilities Council and the Commission for the Blind. However, if no lists are subr: tted the department shall appoint a suitable persc: as surrogate.

(5) Notwithstanding ORS 183.480, if the dectsion of the school board is appealed, the Superintendent of Public Instruction shall conduct an impartial review and render an independent decision on the r.cord compiled at the hearing and shall enter a final order sustaining or reversing the decision of the sihon! board.

(6) Any party aggrieved by the final order rendered under subsection (5) of this section shall have the right to bring it to review by the Court of Appeals pursuant to ORS 183.480.

(7) During any proceedings the child shall remain in the then current educational program placemernt. or if applying for initial admission to a public sinirol, with consent of the parent, guardian or surrogate shall be placed in the public school program unt il all proceedings are completed. 'The school district ani the parents, guardian or surrogate may agree otherwise than as provided in this subsection for the provisi, of of appropriate educational services.

(8) Any decision of the school board relating $t c$ a child being placed in, transferred ifrom or d.nied placement in a special education pro $r a m$ is subject to appeal not more frequently than once each inool year.

(9) Nothing in this section is intended to prisent the temporary exclusion of a pupil from the iublic schools if the condition or conduct of the pupil constitutes an imminent danger to the health or safe $y$ of the pupil or to others. However, no pregnant . hild shall be excluded from the public schools solely on the basis of her pregnancy.

(10) In addition to any other rules which may be adopted pursuant to this section, the Demri. ment of Education shall establish by rule prrict. dures for considering and obtaining special tedu. cation for pregnant children. Such rules hisll include, but not be limited to, the obligation of the school district to:

(a) Inform pregnant students and their parents of the students' rights to special educational services under this section and the availability of such services in the school district or education service district; and

(b) Facilitate the provision of supporting services, including counseling, to pregnant students and inform pregnant students and their parents of the availahility of resources provided by other agencies, including health and social services.

-Approved by the Covernor May 28, 1979.

Filed in the Office of the Secretary of State May 29, 1979. 
Dear

I am writing to ask your cooperation with a needs assessment for adolescent mothers in Washington County, being conducted by second year graduate students in Social Work at Portland State University. These students are completing a research requirement, working under the auspices of the Washington County Task Force on Adolescent Pregnancy. They will complete a three-stage study, one part of which includes data gathered from service providers like you. The results of the study will be shared with County agencies, and will help all of us plan and coordinate services to pregnant or parenting adolescent women in Washington County.

A student will be contacting you within a week to arrange an interview. Their questions will include, but not be limited to: the socio-econamic status and referral sources of clients; services provided; services needed but not available; and agency characteristics. The interview should take less than an hour of your time.

If you have any questions about the purpose or conduct of this needs assessment, please call Nancy Koroloff at 229-4040 or 229-4712. She is the students' research advisor at Portland State University.

I want to thank you in advance for assisting with this project, and look forward to sharing the results with you.

Sincerely,

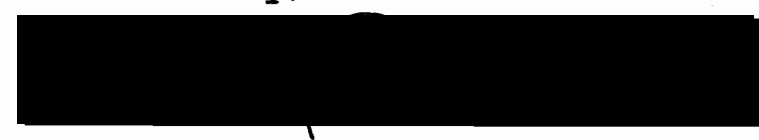

Betty Burkhart, Secretary Washington County Task Force on Adolescent Pregnancy 
SERVICE NEEDS OF ADOLESCENT MOTHERS IN WAGHINGTON COUNTY

INTERVIEW QUESTIONNAIRE: SERVICE PROVIDERS

I. THE AGENCY

1. Respondent's Name:

Title

2. Address:

3. Telephone:

4. Organization:

(Agency Name)

5. Type of Organization. Mark all those that pertain to your agency:

Educational

Public Social Service Agency

Private Social Service Agency
Juvenile Justice Health Other (Specify)

6. What is your service or catchment area:

__ Neighborhood

City

County
School District Statewide Other (Specify)

7. How large is your professional staff? How many work directly with adolescent mothers?

II. CIIENTS SERVED

1. What percentage of your total clientele are adolescent mothers? 
2. Your organization primarily serves what percentage of adolescent mothers in the following age groups:

12 yrs. and under

13-15 yrs

- 16-19 yrs.

3. What percentage of the adolescent mothers served belong to the following economic groups:

low income $(10,000$ and below)

middle income $(10,000-20,000)$

high income $(20,000+)$

4. What percentage of your adolescent mothers you work with belong to the following ethnic groups:

Black

White

Hispanic

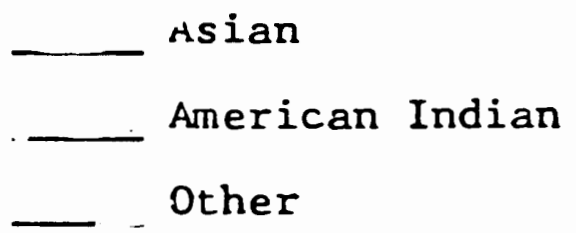

5. In what percentage of your cases do you work with the father of the baby?

$\star \star$ Go to Part III unless conducting school interview.

6. For school interviews only:

a. What is your total enrollment (school district) by grade and sex:

6 th grade. Male

Female

Total

7 th grade. Male

Female

8 th grade Male

Female

9 th grade Male

Female Total

10th grade Male

Fernale Total

11 th grade Male Fernale Total

12 th grade Male Total Total Total 
b. What is the drop-out rate according to grade (age) and sex: (Only those not going on to formal education)

\begin{tabular}{|c|c|c|c|}
\hline 6th grade & Male & Fernale & Total \\
\hline 7 th grade & Male & Fenale & Total \\
\hline 8 th grade & Male & Female & Total \\
\hline 9 th grade & Male & Fenale & Total \\
\hline th grade & Male & Fernale & Total \\
\hline th grade & Male & Female & Total \\
\hline th grade & Male & Female & Total \\
\hline
\end{tabular}

c. What are the primary reasons for dropping out and how many students fall in each category:

Reason

\section{SERVICES}

1. What services are provided to adolescent mothers by your agency:

Counseling

Sex Education

Academic Education

Residential

Health (Medical)
Number of Students

Financial

Employment

Other 
2. How are these clients referred to you:
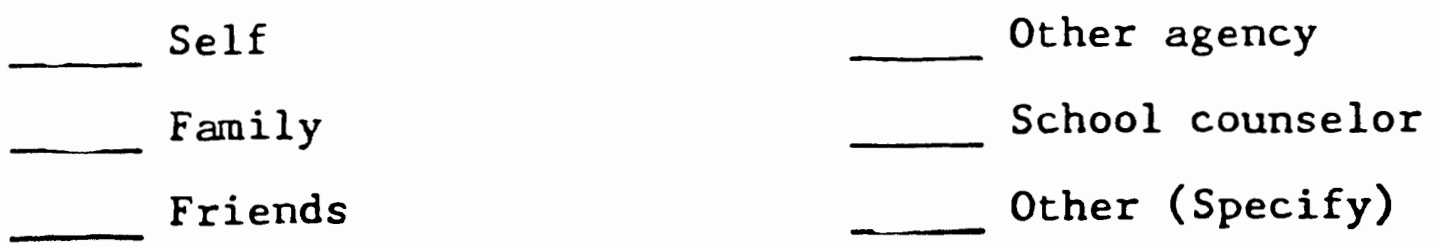

3. When you have identified an adolescent mother, do you refer them to another organization for services?

- Yes

Occasionally

No

To which agencies do you refer most frequently?

4. Does your organization have a waiting list? Yes How long do they have to wait?

If yes, do you refer these to another organization for services? Yes No

5. Are services to adolescent mothers a priority?

6. On the average, how long do you keep contact with adolescent mothers?

7. Are fo'low-up services available to adolescent mother glients? Yes No If yes, what follow-up services are available after delivery, miscarriage, or abortion?' 
8. What is your policy regarding drop-outs from your service?

9. What service to adolescent mothers is used most often?

10. List specific obstacles in your agency in providing services necessary to meet the needs of adolescent mothers.

11. What specific changes do you think should be made to improvi the coordination of services for adolescent mothers between yourself and other organizations?

12. Are you aware of any inter-agency task force groups, workshops, training, or skill sharing groups in Washington County that deal with needs and services to adolescent moth $\longrightarrow$ Yes No

If yes, what are they? 
13. Do you feel that there are sufficient services in Washington County to meet the needs of adolescent mothers? - Yes N No

Please Explain:

14. Do you have any idea of the approximate number of adolescent young women in Washington County who became pregnant in the past year?

IV. PHILOSOPHY AND FUNDING SOURCES

1. Sum up your organization s primary purpose and describe its specific programs and activities:

2. How is your program currently funded? What percentage of these lunds is devoted to assisting the adolescent mother? 
3. In the last six months has your program for adolescent mothers been:

cut back

expanded

remained the same

4. What plans do you have for providing services to adolescent mothers in the future? Do you plan to expand, maintain, or reduce your services? Are there specific projects you plan to pursue?

5. Is there any additional information you think we should be aware of as we look at the needs, resources, and services for adolescent mothers in Washington County? 
Some students at Portland State University, in cooperation with the Department of Public Health in Washington County, are collecting information concerning the needs of recent and prospective young mothers. We would appreciate it if you would help us by taking a few minutes to fill out the attached questionnaire, which is designed to sort out what community services you have used and in what areas you have found that the services you needed were lacking. Your ideas will be used as part of a broad effort to better serve young mothers.

The questionnaire is confidential. You need not include your name. And feel free to leave blank any questions you would prefer not to answer.

If you need to ask about the questionnaire, you may contact either Marietta Sorenson of Washington County Department of Dublic Health (640-3480), or Nancy Koroloff of Portland State University (229-4712).

We are including a return envelope for your convenience and we would like to thank you in advance for your time and your much needed help.

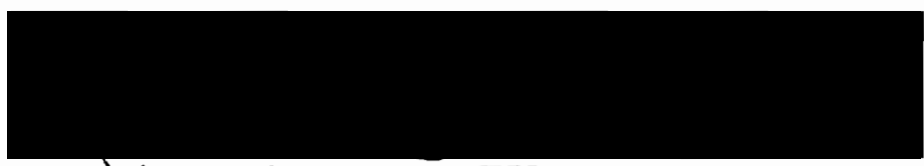

Marietta Sorenson, CHN

Dept. of Public Health

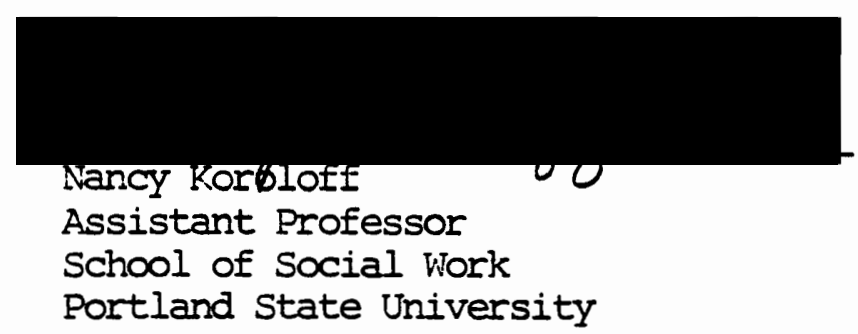

$/ \mathrm{jm}$

$12 / 2 / 80$

Attachment 
1. $A G E$

2. RACE

(check one)

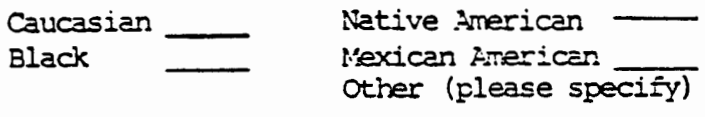

3. VIIERE DO YOU LIVE?

(check one)

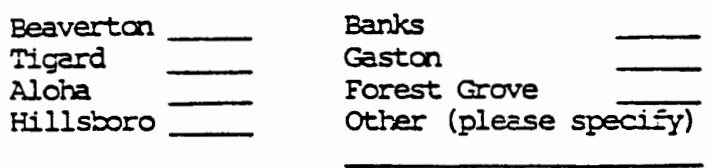

4. TARTLI STATUS

(check one)

$$
\begin{aligned}
& \text { Single (never married) } \\
& \text { Engaged } \\
& \text { Married }
\end{aligned}
$$

Separated

Divorced

5. WHO DO YOU LTVE WITH?

(check one)

$$
\begin{aligned}
& \text { Live with parents } \\
& \text { Live alone } \\
& \text { Live with husband }
\end{aligned}
$$

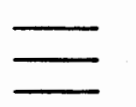
Iive with bovfriend Iive in Foster Care other (please specify)

6. HOW DO YOU SUPPORT YOURSELF?

(check all that apply)
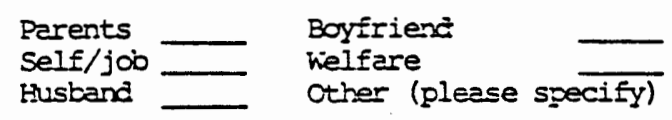

7. In'Cane

(check ane)

$$
\begin{aligned}
& \text { Less than } \$ 5,000 \\
& \$ 5,000 \text { to } \$ 10,000 / y \text { r } \\
& \$ 10,000 \text { to } \$ 15,000 / y \text { r } \\
& \$ 15,000 \text { to } \$ 20,000 / y 1 \\
& \$ 20,000 \text { to } \$ 25,000 / y \text { r } \\
& \$ 25,000 \text { to } \$ 30,000 / y x \\
& \text { whose incane is this? }
\end{aligned}
$$

8. ARE YOU FREGIANT AT THIS TIIE?

$$
\text { Yes __ No }
$$

If "yes",

How far along are you? Are you going to,

(check one)

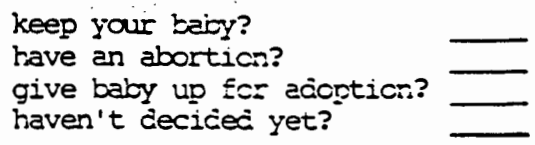

has this a planned precrancy?

$$
\text { Yes _ is }
$$


$-2-$

9. HAVE YOU BEEN PREGVANT MEFCRE?

Yes No

If "yes",

How many tines?

Did you, keep your baby? lave an abortion? give baby up for adoption? other? (please specify)

Was your pregnancy (s) planned?

Yes ivo

10. ARE YOU RECEIVING NOW OR DD YOU RDCEIVE (check all that apply)

Before baby was born,

Meäical care?

At what time in your pregnancy? month

Where did you get this care? private doctor public health nurse through an agency hospital other (please specify)

After baidy was born,

Medical care? Yes
How long atter?
\# of manths
Where did you get this care?
private doctor
public health nurse
through an agency
hospital
other (please specify)

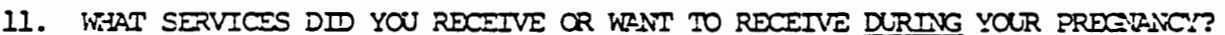
(I-ARK ALL THAT YOU RDCETVED WITH AN "R". MARK ALI THAT YOU WANT OR WANTED TO RECEIVE, AID HEVE NOT, WITH A "W".)

birth cantrol information

legal insormation

abortion courseling nutritional guidance acoption counseling

financial aid

job training

clothing

housing

transportation

alternative school

career counseling

parenting information

young mother's group

child care

other (please specify) 
$-3-$

12. WHAT SERUICES DID YOU RECEIVE OR WANT TO RECEIVE A TERR YOUR PRDGNALCY? IF YOU GAVEN'T FAD YOUR BABY YET, PLEASE INDICATE IACSE SERVICES YOU NANT TO RECEIVE.

(I.ARK AIL TIAT YOU RECETVDD WITH AN "R". MARK ALI TUAT YOU TANT OR WANTED TO RECEIVE, AND UAVE NOT, WTIFI A "N".)

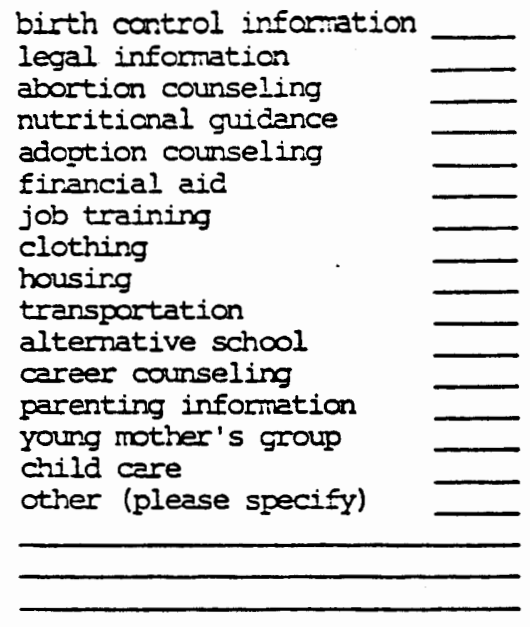

13. WHICH MGEXCIES OR INDIVIEUALS HAVE FEIPED YOU IN IHFSE AREAS?

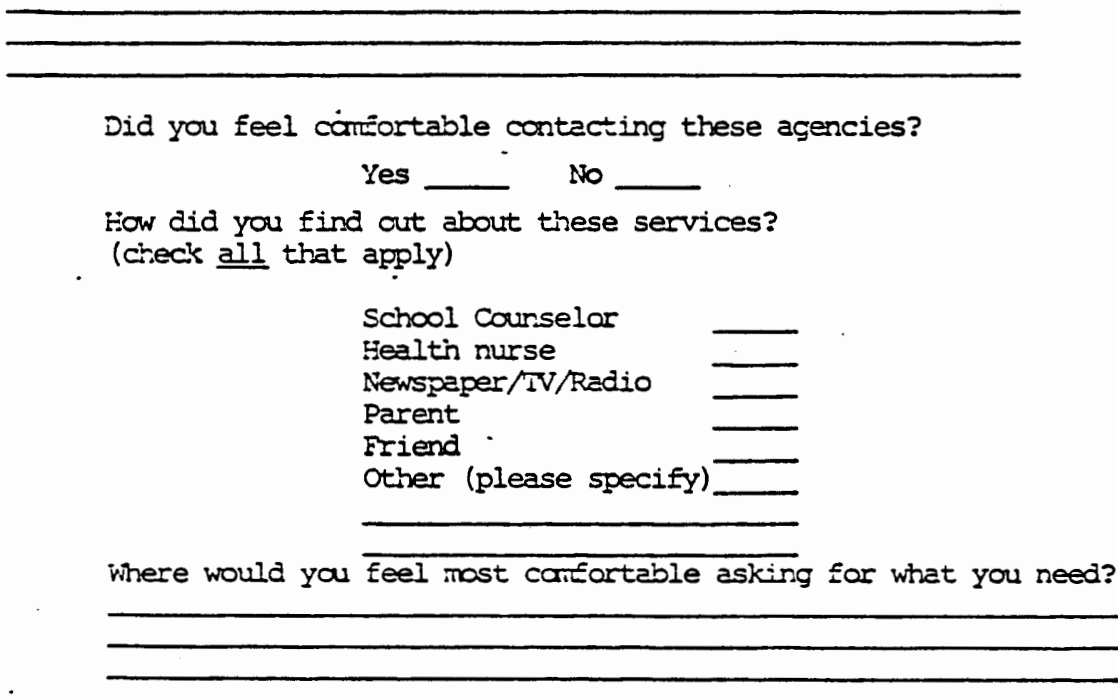

14. IVIAT SCFOOL DID YOU ATTEND BEFORE YOU BECAME PRDGNANT?

15. DID YOU CONTINUE YOUR EDUCATION AFTER YOU BECANE ESBGTANT?

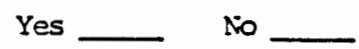

If "yes", where?

If "no", what keeps you, or kept you, fram continuing school?

16. HAVE YOU RECEIVDD

$$
\begin{aligned}
& \text { GनD? } \\
& \text { High School Diplama? }
\end{aligned}
$$

17. DID YOU KUON THAT TEE SCHOOL MUST LEIP YOU CONTAUE YOLR EDUCATION, IF YOU IFITT TO? 
$-4-$

If "yes", who infonred you of this?

18. DID AWY SGENCY CONTACT YOU AFTER YCUR BABY IRS BCRN?

$$
\text { Yes __io }
$$

If "yes", which agency contacted you?

19. WEAT SERVICES CR HEID DO YOU (CR DID YOU) FEI YOU VIDD, SUT IIERE LNABLE TO FIND?

20. WERE YOU DENIED SERVICES BY AIYYONE?

Yes _ ito

If "yes", do you know why? 